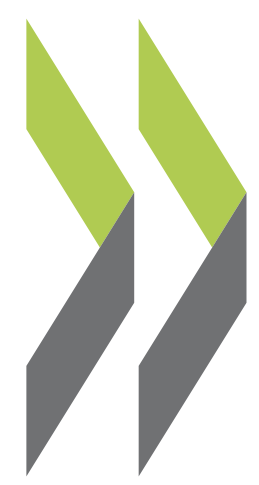

OECD Science, Technology and Industry Working Papers $2002 / 02$

\title{
Plant Turnover and Productivity Growth in Canadian Manufacturing
}

\section{John R. Baldwin, Wulong Gu}


Organisation de Coopération et de Développement Economiques

DIRECTORATE FOR SCIENCE, TECHNOLOGY AND INDUSTRY

STI WORKING PAPERS 2002/2

PLANT TURNOVER AND PRODUCTIVITY GROWTH IN CANADIAN MANUFACTURING

John R. Baldwin and Wulong Gu 


\section{STI Working Paper Series}

The Working Paper series of the OECD Directorate for Science, Technology and Industry is designed to make available to a wider readership selected studies prepared by staff in the Directorate or by outside consultants working on OECD projects. The papers included in the series cover a broad range of issues, of both a technical and policy-analytical nature, in the areas of work of the DSTI. The Working Papers are generally available only in their original language - English or French - with a summary in the other.

Comment on the papers is invited, and should be sent to the Directorate for Science, Technology and Industry, OECD, 2 rue André Pascal, 75775 Paris Cedex 16, France.

The opinions expressed in these papers are the sole responsibility of the author(s) and do not necessarily reflect those of the OECD or of the governments of its Member countries.

http://www.oecd.org/sti/working-papers 
DSTI/DOC(2002)2

\title{
PLANT TURNOVER AND PRODUCTIVITY GROWTH IN CANADIAN MANUFACTURING
}

\author{
John R. Baldwin \\ Wulong Gu \\ Micro Economic Analysis Division* \\ Statistics Canada
}

\begin{abstract}
Entry is important because new firms and new plants provide an important source of competition to incumbents. They are a source of new products and technologies. In this paper, we outline the size of the turnover in plants that have entered and exited the Canadian manufacturing sector over each of the last three decades - 1973-79, 1979-88 and 1988-97. We also examine the contribution of plant turnover to labour productivity growth in the manufacturing sector over the three periods. Plant turnover makes a significant contribution to productivity growth as more productive entrants replace exiting plants that are less productive. We also find that a disproportionately large fraction of the contribution of plant turnover to productivity growth is due to multi-plant or foreign-controlled firms closing down and opening up new plants. The plants opened up by multi-plant or foreign-controlled firms are typically much more productive than those opened by single-plant or domestic-controlled firms.
\end{abstract}

Authors are listed in alphabetical order. We would like to thank Bob Gibson and Andrée Girard for research assistance. This paper was prepared for the productivity growth project of the OECD. Views expressed in this paper do not necessarily reflect those of Statistics Canada or the OECD. 


\title{
ENTRÉES ET SORTIES D'USINES ET CROISSANCE DE LA PRODUCTIVITÉ DANS LE SECTEUR MANUFACTURIER AU CANADA
}

\author{
John R. Baldwin \\ Wulong Gu \\ Micro Economic Analysis Division* \\ Statistics Canada
}

Résumé

Les entrées sur le marché sont importantes parce que les nouvelles entreprises et les nouvelles usines, qui génèrent de nouveaux produits et de nouvelles technologies, font une vive concurrence aux entreprises existantes. Dans le présent document, nous examinons l'importance du roulement des usines dans le secteur manufacturier canadien, c'est-à-dire le nombre d'entrées et de sorties, au cours des trois dernières décennies, soit de 1973 à 1979, de 1979 à 1988 et de 1988 à 1997. Nous examinons aussi la contribution de ce roulement à la croissance de la productivité du travail dans le secteur manufacturier au cours de ces trois périodes. Le roulement des usines contribue de façon importante à la croissance de la productivité, les usines entrantes plus productives remplaçant les usines sortantes moins productives. Par ailleurs, nous constatons qu'une part disproportionnellement élevée de l'effet des entrées et des sorties sur la croissance de la productivité est attribuable à la fermeture d'usines et à l'ouverture de nouvelles usines par des entreprises à plusieurs usines ou sous contrôle étranger. Habituellement, les usines ouvertes par des entreprises à plusieurs usines ou sous contrôle étranger sont beaucoup plus productives que celles ouvertes par des entreprises à une seule usine ou sous contrôle canadien.

* Les auteurs sont indiqués par order alphabétique. Nous tenons à remercier en particulier Bob Gibson et Andrée Girard pour toute leur aide en matière de recherche. Ce papier a été rédigé dans le cadre du projet mené par l'OCDE sur la croissance de la productivité. Les opinions qui y figurent ne sont pas forcément celles de Statistique Canada ni de l'OCDE. 
DSTI/DOC(2002)2

\section{EXECUTIVE SUMMARY}

Productivity measures are usually produced for the entire economy or for an entire industry, not for individual businesses. This macro growth is the result of the sum of the growth in the underlying micro units that make up the population of firms.

Overall productivity growth may be the result of entry and exit or it may come from incumbents. Within the incumbent population, it may be produced primarily by domestic as opposed to foreign producers. Understanding which of the underlying producers are responsible for overall productivity growth is important to public policy. If it comes mainly from entry and exit, maintaining an open flexible economy that supports these adjustments is important. If it comes mainly from domestic firms, then it may be that the foreign sector is no longer the vehicle for the transfer of advanced technology to Canada that it once was.

This paper is both methodological and empirical. The first part of the paper asks how we can measure the contribution to overall productivity growth of the entry and exit components of firm and plant turnover. We examine several formulae that have been used in the literature to decompose the growth in productivity over time into separate entry and exit components. We argue that the decompositions are all too often treated as mechanical exercises. Each of the decompositions is mathematically correct, but the economic meaning underlying each depends on implicit assumptions about the dynamic process that is taking place within the firm and plant population. In particular, each formula is directly associated with a counterfactual assumption about the replacement process at work in the population of firms and plants - the process that has some businesses taking away market share from others.

The most frequently used formula assumes that entrants replace existing plants. We argue that the empirical evidence suggests that, at least for Canada, entrants essentially replace exits. Small firms and plants are not likely to replace larger existing firms and plants in most situations. New firms are smaller than the average incumbent. They pay lower wages. They are less productive (Baldwin and Rafiquzzaman, 1995). Competition takes place within subgroups of an industry (Neuman, 1978). New small firms are more likely to compete against other small firms. In doing so, entrants are most likely to displace exits.

After outlining the methodological issues that must be resolved before measurement can take place, the second section examines several empirical issues using the Canadian Census of Manufactures and a special longitudinal database on plants that has been derived therefrom. It examines changes that have occurred in each of the 1970s, the 1980s, and the 1990s. In doing so, it poses the following questions:

\section{How important is the entry and exit process over the last three decades and has it changed?}

Entry and exit are large. Some 29\% of all manufacturing plants in existence in 1997 are new plants that entered over the 1988-97 period. Some $47 \%$ of the manufacturing plants operating in 1988 were no longer in operation in 1997.

When measured in terms of employment, entry and exit rates are lower but still significant. The two comparable employment entry and exit rates for the $1988-97$ period are $20 \%$ and $27 \%$, respectively. 
The employment share of entrants and exits has been higher in the 1980s and 1990s compared to the 1970s. During the 1990s, exits have shot up relative to entrants, probably because of restructuring that is associated with North American trade liberalisation.

\section{What is the growth trajectory of entrants?}

Entering plants undergo both a selection and a learning process as competition culls out less productive plants and the survivors improve productivity. The paper examines the growth process of entrants which came into existence in the 1980s and then survived over the 1990s. We find that the output and employment of these entrants grows more quickly than those of incumbents who also survive, but the labour productivity of surviving entrants grows less quickly than that of surviving incumbents. While entrants therefore learn enough to improve their productivity, they are not learning as quickly as incumbent survivors.

On the other hand, those members of the entrant cohort who fail are much less productive than those who survive. As a result, the average productivity of a cohort of entrants tends to catch up with the average productivity of incumbents - but this is caused by the culling of the less-efficient plants in an entry cohort.

In summary, new plants that manage to survive are considerably more productive than those who fail. They also become more productive than incumbents who fail. They are not more productive than the average incumbent and they are, therefore, unlikely to have gained market share from this group on average. Productivity decompositions that fail to recognise this fact will produce misleading estimates of the contribution of entry to the productivity process. In particular, they will tend to bias downwards the contribution that entry makes.

\section{How important is the contribution that is made by entry and exit to labour productivity growth?}

Entering plants are considerably more productive than the exiting plants they displace. Using continuing incumbents as the metric to which each is compared, we find that, during the period 1988-97, entrants are $7 \%$ less productive than incumbents in 1997, while exits are almost $30 \%$ less productive than incumbents in 1988 - a difference of some 22 percentage points.

As a result of this differential, the paper argues that the correct calculations show that plant turnover from entry and exit contributes $15-25 \%$ of labour productivity growth during the 1973-79, 1979-88, and 1988-97 periods. It is important to note that it is not possible to separate the effect of entry from exit; since one causes the other, it is the net effect of the two taken together that is sensibly measured.

The contribution that entry and exit make to productivity growth is generally larger than their share of employment. However, over the three periods studied, their contribution to labour productivity growth has been falling. Plant turnover contributes a quarter of productivity growth in the 1973-79 period, $20 \%$ in the $1979-88$ period, and $15-20 \%$ in the $1988-97$ period.

\section{Are the most productive plants growing most rapidly?}

To better explain the nature of the growth process that is taking place in the continuing population, we calculate correlations of labour productivity growth, output growth, employment growth, and initial labour productivity and employment levels across continuing plants. Two patterns consistently emerge. 
First, there is virtually no correlation between output growth and initial labour productivity growth. That is, if we divide the population of plants into two groups based on initial labour productivity at the beginning of the period, we cannot predict future growth in market share.

Second, some plants do, however, gain market share. These plants also increase their share of employment - there is a positive correlation between output and labour growth. There is a positive correlation between output growth and labour productivity growth. There is a substantial shifting of relative position based on output that is associated with changes in relative productivity.

\section{Are all entrants equally important?}

All entrants do not contribute equally to productivity growth. A disproportionately large share of the contribution to labour productivity growth is due to foreign-controlled firms opening up or closing down plants. This reinforces other research (Baldwin and Dhaliwal, 2000) that has found foreign-controlled plants to be more productive than domestic plants and confirms that this difference has been reinforced by changes at the margin of the population that come from entry and exit.

The proportion of labour productivity growth that is accounted for by entry has been relatively constant over the last three decades; but the share of this that has originated in domestic plants has fallen over the period. Over the 1988-97 period, foreign-controlled entrants account for 20\% of employment of all entering plants and foreign-controlled exiters account for $28 \%$ of employment of all exiting plants. Plant turnover of foreign-controlled firms provides $60 \%$ of the contribution from total plant turnover.

In summary, foreign-controlled plants have become increasingly important as a source of entry. They have become increasingly large relative to domestic entrants. They have become increasingly productive relative to both domestic entrants and relative to incumbents. The latter increase was particularly large in the period post FTA and NAFTA.

\section{Are small single plant entrants the engines of growth?}

The paper also examines the effect of the entry of small independent entrants as opposed to the creation of new plants that are part of large multi-plant enterprises. The closed plant and new plant associated with multi-plant firms are much larger than their counterparts in single-plant firms. Almost all of the contribution of plant turnover to productivity growth is due to more productive new plants of multiplant firms displacing exiting plants of multi-plant firms.

It is also noteworthy that the continuing plant contribution of multiplant firms greatly exceeds that of single-plant firms. A remarkable feature then of productivity growth in Canadian manufacturing is the predominant role of multi-plant firms. Multi-plant firms account for almost all of the productivity growth in Canadian manufacturing in the three periods we examined. Multi-plant firms account for $85 \%$ of growth in labour productivity in the 1973-79 period and more than 90\% of growth in the 1979-88 and 1988-97 periods. In 1997, multi-plant firms produced $75 \%$ of output and employed $60 \%$ of workers in Canadian manufacturing. The plants that are part of multi-plant firms accounted for $22 \%$ of all plants. The contribution of multi-plant firms to productivity growth is much greater than their share of employment. All of this suggests that small independent single-plant firms have had very little impact on aggregate productivity growth. 


\section{Are there differences across industries in the importance of entrants?}

While there are substantial differences at the industry level in terms of the importance of entry, the important issue addressed in this paper is the extent to which this changes over time. We find that there are substantial similarities across time in the importance of entry and exit. This indicates that the underlying forces that allow for turnover and renewal via entry and exit are relatively constant.

The factor that strongly influences the contribution that is made by the entry of new plants and the exit of old plants to productivity growth is the productivity of each group relative to continuers or relative to one another. This variable will be determined by the ability of new plants to adopt new technologies relative to existing plants. In turn, this will be a function of the extent to which new technologies are best introduced into a new environment, or the extent to which the new technologies are best combined with other technologies in existing plants.

Here there is much less stability across decades. This suggests that the underlying technological factors that facilitate productivity growth via new entry are not stable over time. The paper then proceeds to test whether changes in trade intensity might be related to entry and exit. We find that increases in trade intensity (especially in intra-industry trade) in the 1990s have been associated with more entry and more exit and less net entry (gross entry less gross exit) on balance. 


\section{TABLE OF CONTENTS}

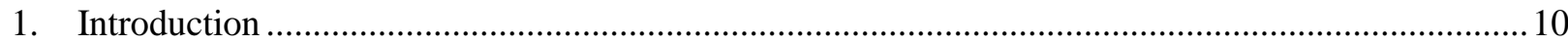

2. Alternative methodologies for measuring the contribution of plant turnover to productivity growth 12

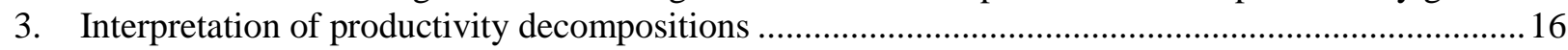

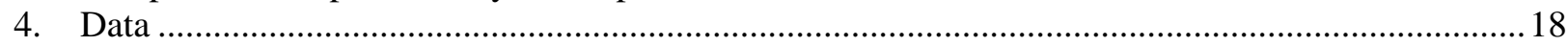

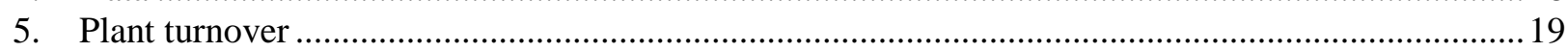

5.1 Plant turnover and productivity differentials among entering, exiting and continuing plants .. 19

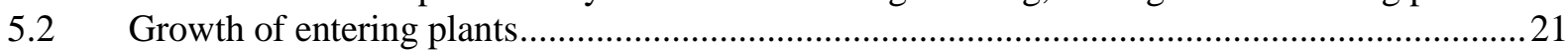

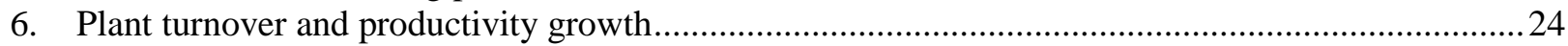

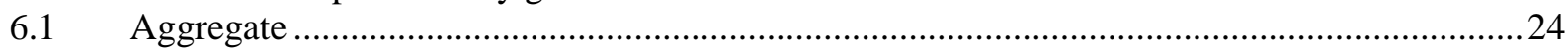

6.2 Plant turnover among foreign-controlled vs. domestic-controlled plants ................................26

6.3 Plant turnover among single-plant vs. multi-plant firms ......................................................... 31

7. Plant turnover and productivity growth at industry-level manufacturing ......................................... 34

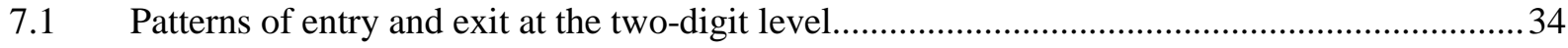

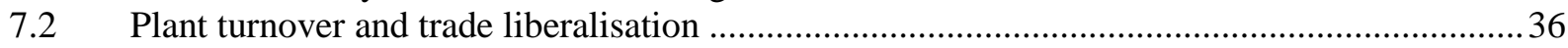

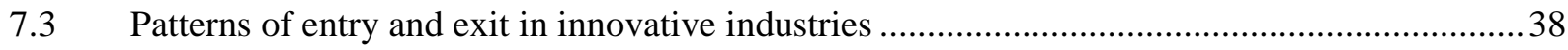

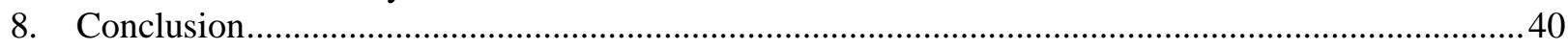

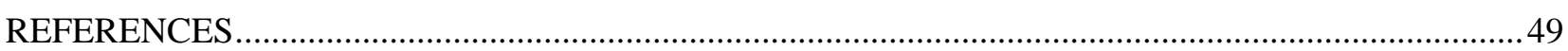




\section{Introduction}

A large number of plants enter and exit Canadian manufacturing every year. About $40 \%$ of the manufacturing plants in 1997 are new plants that entered over the 1988-97 period, while half of the plants in 1988 were no longer operating in 1997. The objective of this paper is to examine the contribution of plant turnover to labour productivity growth in Canadian manufacturing over the three periods: 1973-79, 1979-88 and 1988-97. The last period has been accompanied by a dramatic increase in export and import intensity as a result of the Free Trade Agreement (FTA) between Canada and the United States. In examining the general behaviour of plant turnover over the past three periods, we are looking for changes that may have resulted from industrial restructuring associated with the increases in trade liberalisation that have occurred in the most recent period.

The sheer size of the amount of plant renewal via plant openings and plant closings taking place is a testament to its importance. Competition is intense when the identity of the players changes and when firms are both closing and opening plants. Despite this, it is important to have supportive evidence of an effect of plant turnover on the performance of an industry.

Productivity growth is an important measure of performance and new firms that establish new plants affect the productivity of an industry. New firms experiment with new ideas and processes and provide an important source of competition. Unfortunately, productivity growth generally tends to be studied only at the aggregate industry level and therefore the effects of entry per se on productivity growth have not been well delineated. While Geroski (1991) has tried to relate technical progress, efficiency and productivity growth at the industry level to entry rates, his approach is somewhat of a "black-box", using as it does aggregate industry productivity measures and entry rates. It does not explore the process that is driving productivity at the microlevel and, therefore, misses important detail. The link between productivity growth and entry requires a more detailed examination of data at the plant and firm level.

Even when this is done, the evidence on the effect of turnover on productivity is mixed. Some authors who have studied this phenomenon report that the contribution of entrants is relatively small (Hazledine, 1985; Bailey et al., 1992; Griliches and Regev, 1995). More recently, cross-country studies by the OECD (2001) suggest that it is not so much entry as exit that matters. On the other hand, Baldwin (1995) and Haltiwanger (1997) find that the entry of new firms makes a substantial contribution to productivity growth.

The purpose of this paper is two-fold. First, we examine the history of the last three decades to see whether the contribution that entry has made to productivity growth in Canada has changed. Second, we consider the alternative measures that have been suggested to capture the contribution of entry to productivity growth. We not only revisit the ways in which the contribution of entry to productivity growth may be measured, we also explain the implicit differences in the assumptions that underlie each measure. We then examine the extent to which the different approaches yield different answers to the importance of entry in Canada. Finally, we ask whether particular types of entry are more important than others.

A number of previous studies have examined the implication of plant turnover for productivity growth in Canadian manufacturing (Baldwin and Gorecki, 1991; Baldwin, 1995). Using a longitudinal file developed from the Annual Census of Manufactures, Baldwin (1995) finds that entrants are typically more productive than exiting plants and concludes that about $30 \%$ of labour productivity growth in Canadian manufacturing can be attributed to entry and exit over the 1970-79 period. In this paper, we extend the estimates presented in Baldwin (1995) to subsequent periods and examine the difference in plant turnover between foreign- and domestic-controlled plants, between multi-plant and single-plant firms, and across different industries. 
A distinguishing feature of Canadian manufacturing is the large presence of foreign-controlled plants (Baldwin and Dhaliwal, 2000). In 1997, foreign-controlled plants accounted for $10 \%$ of plants in total manufacturing, contributing 30\% of employment and half of output. Consequently, in this paper, we examine the role of plant renewal among foreign-controlled plants. In particular, we ask whether their contribution to productivity growth is larger than the contribution made by the domestic sector and whether it has been changing over time. We are particularly interested in finding out whether it has gone up in the post-FTA period.

We also examine the relative importance of plant turnover among multi-plant $v s$. single-plant firms. New plants can be associated with the entry of a new firm or they can be associated with an existing firm. One way of distinguishing between the two is to examine the effect of new plants of single firms (which by definition have to be new firms) and new plants belonging to multi-plant firms (which by definition are existing firms). Baldwin (1995) argues that plants started up by multi-plant firms are at the frontier of new knowledge and techniques, and finds that the start-ups by multi-plant firms are much more productive than average manufacturing plants. However, the contribution of the multi-plant as opposed to the single-plant group (de novo entrants) has not previously been measured for Canada. This lacunae is rectified here.

The paper also examines the extent to which the plant renewal process is more important in some sectors than others - both in terms of its size and its contribution to productivity growth. The 1990s have been characterised by rapid technical progress, especially in those industries that produce semiconductors, computers and telecommunication equipment. Plant turnover is perceived to be more rapid and new plants perceived to contribute more strongly to productivity growth in the ICT (information and communication technology) sector than in other industries (OECD, 2001). To examine the issue, we divide all manufacturing industries into three broad sectors: the core (ICT-related plus Chemicals), secondary and other sectors, and examine the difference in plant turnover among the three sectors. ${ }^{1}$

In Section 2 of this paper, we present alternative methodologies that have been used to decompose aggregate productivity growth into components, one of which is taken to represent the effect of plant turnover (entering and exiting plants), and another, that of continuing plants. In Section 3, we discuss the interpretation that should be placed on the terms that are derived from these traditional decompositions. In Section 4, we describe the data that are used.

Section 5, the first empirical section, documents the extent of plant turnover for the manufacturing sector as a whole, and examines the differences in average labour productivity among entering, exiting and continuing plants.

Also, in Section 5, we examine the importance of selection vs. learning in the post-entry growth of new plants. One of the most important determinants of the impact of plant turnover on productivity growth in the long run is the post-entry growth of entering plants. Entering plants typically undergo both a selection and learning process as market competition sorts out high-productivity from low-productivity plants and the survivors increase their productivity. Selection occurs as the least productive plants are culled from an entry cohort. Learning occurs as the remaining entrants who start out at a disadvantage relative to incumbents improve their productivity.

We then combine the turnover and productivity statistics and use them to measure the contribution of plant turnover to productivity growth in aggregate manufacturing over the three periods: 1973-79, 1979-88

1. The core sector includes machinery, electrical equipment and chemicals where the dominant source of innovation is product innovation. The secondary sector mainly undertakes process innovation while the "other" sector conducts both product and process innovation (Robson et al., 1988; Baldwin and Hanel, 2002). 
and 1988-97. In this section, we also examine the relative contribution of plant turnover among foreigncontrolled vs. domestic-controlled plants to aggregate productivity growth as well as the relative role of plant turnover among single-plant firms $v s$. multi-plant firms.

Section 7 examines differences in plant turnover and productivity growth for 22 manufacturing industries at the two-digit SIC level (Standard Industrial Classification, 1980). We briefly examine the changes that have occurred over the last three decades and their relationship to changes in export and import intensity. We then divide the 22 two-digit industries into three groups, using a taxonomy based on the intensity of innovation taking place therein. These groups are the core, secondary and tertiary "other" sectors. Differences in plant turnover among the three sectors are then examined. A brief conclusion follows in Section 8.

\section{Alternative methodologies for measuring the contribution of plant turnover to productivity growth}

Productivity at the aggregate level is just a weighted average of the productivity of individual businesses. For expository purposes, we will refer to the business unit as a firm - although it could equally well be thought of as plant in the following section. That is

1) $P_{t}=\sum s_{i t} p_{i t}$, where $P_{\mathrm{t}}$ is aggregate labour productivity in period $t, s_{i t}$ is the employment share of firm $i$ in period $t$, and $p_{i t}$ is labour productivity of firm $i$ in year $t$.

Changes in productivity will occur as some firms improve productivity and as employment share changes. Changes in employment shares reflect firm turnover (entry and exit) as well as the growth and decline that occur within the continuing-firm sector. The contribution of continuing firms emanates from productivity growth taking place within individual firms and employment shifts between individual firms from those that are less productive to those that are more productive. ${ }^{2}$ In this section, we examine alternative ways to measure each - with our primary emphasis on the issue of the contribution of entrants and exits to productivity growth.

Previous empirical studies have used different methods to measure the contribution of firm turnover to productivity growth (see Foster et al., 1998, for a review). For robustness, we use three alternative methods in this paper. The first method is proposed by Foster et al. (1998) (FHK for short). The second is the decomposition approach used by Griliches and Regev (1995) (GR for short). This has recently been adopted by the OECD in their inter-country comparison of the importance of entry for productivity growth. The final method is the one used by Baldwin and Gorecki (1991) and Baldwin (1995).

All of the decomposition methods start with the identity that relates changes in labour productivity of an industry to that of firms comprising the industry:

2) $\Delta P_{t, t-\tau}=\sum_{i \in I} s_{i t} p_{i t}-\sum_{i \in I} s_{i t-\tau} p_{i t-\tau}$, where $\Delta P_{t, t-\tau}$ is the change in labour productivity of an industry between year $t$ and year $(t-\tau), s_{i t}$ is the employment share of firm $i$ in period $t, p_{i t}$ is labour productivity of firm $i$ in year $t$.

2. Alternatively, we can decompose the contribution of continuing plants into a component made up of those plants gaining market shares and one comprising those plants losing market shares (Baldwin, 1995). 
Between year $t-\tau$ and year $t$, some firms will be operating throughout the period. Those firms are called "continuing firms" - the set C. Some firms operating in the end year $t$ will be the firms that have entered the industry between $t-\tau$ and $t$. Those firms are referred to as entering firms - the set E. Some firms operating in the base year $t-\tau$ are no longer operating in the end year $t$. They are the exiting firms the set X.

Changes in productivity can be rewritten as the difference between the weighted average of continuers and entrants in the second period minus the weighted average of continuers and exits in the first period:

3) $\Delta P_{t, t-\tau}=\left(\sum_{i \in C} s_{i t} p_{i t}+\sum_{i \in E} s_{i t} p_{i t}\right)-\left(\sum_{i \in C} s_{i t-\tau} p_{i t-\tau}+\sum_{i \in X} s_{i t-\tau} p_{i t-\tau}\right)$

Or, rearranging Equation 3, the growth in productivity is simply the growth in productivity in the continuing segment plus the growth that is added by the entering minus exiting firms.

4) $\Delta P_{t, t-\tau}=\left(\sum_{i \in C} s_{i t} p_{i t}-\sum_{i \in C} s_{i t-\tau} p_{i t-\tau}\right)+\left(\sum_{i \in E} s_{i t} p_{i t}-\sum_{i \in X} s_{i t-\tau} p_{i t-\tau}\right)$

The change that is due to continuers (the first bracket in Equation 4) can be rewritten by adding and subtracting a term and judiciously rearranging existing terms. First add and subtract:

5) $\sum_{i \in C} s_{i t} p_{i t-\tau}$ from the first term of Equation 4 and group terms to yield:

6) $\sum_{i \in C} s_{i t}\left(p_{i t}-p_{i t-\tau}\right)+\sum_{i \in C}\left(s_{i t}-s_{i t-\tau}\right) p_{i t-\tau}$

Similarly, add and subtract:

7) $\sum_{i \in C} s_{i t-\tau} p_{i t}$ from the first term of Equation 4 and group terms to yield:

8) $\sum_{i \in C} s_{i t-\tau}\left(p_{i t}-p_{i t-\tau}\right)+\sum_{i \in C}\left(s_{i t}-s_{i t-\tau}\right) p_{i t}$

The two first terms in Equations 6 and 8 measure the change in productivity of continuers weighted by terminal and opening period employment share respectively. The last term in both expressions is just the changes in labour shares weighted by the opening or terminal values of labour productivity respectively.

The mean of Equations 6 and 8, which is itself equal to the first term in Equation 4, is:

9) $\sum_{i \in C} \overline{s_{i}}\left(p_{i t}-p_{i t-\tau}\right)+\sum_{i \in C}\left(s_{i t}-s_{i t-\tau}\right) \bar{p}_{i}$

This differs from Equations 6 and 8 in that mean shares and mean productivity are used, rather than first or terminal period values. Using this decomposition of the continuing segment plus the difference in productivity generated by entrants and exits yields:

$$
\text { 10) } \Delta P_{t, t-\tau}=\sum_{i \in C} \overline{s_{i}}\left(p_{i t}-p_{i t-\tau}\right)+\sum_{i \in C}\left(s_{i t}-s_{i t-\tau}\right) \bar{p}_{i}+\left(\sum_{i \in E} s_{i t} p_{i t}-\sum_{i \in X} s_{i t-\tau} p_{i t-\tau}\right)
$$

This decomposition can be extended to rewrite the effect of entrants and exits. To do so, a new term is added that equals zero and thus does not change the overall value of Equation 2. Recognising that changes 
in the share of continuers over the period must just equal the difference between the share of entrants and exits, that is:

11) $\sum_{i \in C}\left(s_{i t}-s_{i t-\tau}\right)=-\left(\sum_{i \in E} s_{i t}-\sum_{i \in X} s_{i t-\tau}\right)$

Multiplying both sides by an arbitrary value of $\bar{P}$, the mean for the industry, gives:

12) $\bar{P} \sum_{i \in C}\left(s_{i t}-s_{i t-\tau}\right)+\bar{P}\left(\sum_{i \in E} s_{i t}-\sum_{i \in X} s_{i t-\tau}\right)=0$

Then, subtracting Equation 12 from Equation 10 yields:

$$
\begin{aligned}
\Delta P_{t, t-\tau} & =\sum_{i \in C} \overline{s_{i}}\left(p_{i t}-p_{i t-\tau}\right)+\sum_{i \in C}\left(s_{i t}-s_{i t-\tau}\right)\left(\bar{p}_{i}-\bar{P}\right) \\
& +\sum_{i \in E} s_{i t}\left(p_{i t}-\bar{P}\right)-\sum_{i \in X} s_{i t-\tau}\left(p_{i t-\tau}-\bar{P}\right)
\end{aligned}
$$

This is the formula used by Griliches and Regev (1995). The first term in this decomposition is categorised as the within-firm component and measures the contribution of productivity growth within continuing firms holding their shares fixed. The second term is referred to as the between-firm component and captures the effect of the compositional shift in employment shares among continuing firms. The between-firm component contributes positively to productivity as output or employment shifts towards firms that are more productive than the average. The last two terms are taken to represent the contribution of firm turnover (entering and exiting firms).

Foster et al. (1998) use a modification of the same approach. Rather than averaging shares and productivity across time, they start with Equation 8 but then add and subtract:

$\sum_{i \in C}\left(s_{i t}-s_{i \leftarrow \tau}\right)\left(p_{i t-\tau}\right)$, which in the place of Equation 13 yields:

14)

$$
\begin{aligned}
& \Delta P_{t, t-\tau}=\sum_{i \in C} s_{i t-\tau}\left(p_{i t}-p_{i t-\tau}\right)+\sum_{i \in C}\left(s_{i t}-s_{i t-\tau}\right)\left(p_{i t-\tau}-\bar{P}\right) \\
& +\sum_{i \in C}\left(s_{i t}-s_{i t-\tau}\right)\left(p_{i t}-p_{i t-\tau}\right)+\sum_{i \in E} s_{i t}\left(p_{i t}-\bar{P}\right)-\sum_{i \in X} s_{i t-\tau}\left(p_{i t-\tau}-\bar{P}\right)
\end{aligned}
$$

And finally, they replace the industry average productivity for all firms taken over the two periods $(\bar{P})$ with the industry productivity for both continuers and exits in the first period $\left(P_{t-\tau}\right)$, which yields:

$$
\begin{aligned}
& \Delta P_{t, t-\tau}=\sum_{i \in C} s_{i t-\tau}\left(p_{i t}-p_{i t-\tau}\right)+\sum_{i \in C}\left(s_{i t}-s_{i t-\tau}\right)\left(p_{i t-\tau}-P_{t-\tau}\right) \\
& +\sum_{i \in C}\left(s_{i t}-s_{i t-\tau}\right)\left(p_{i t}-p_{i t-\tau}\right)+\sum_{i \in E} s_{i t}\left(p_{i t}-P_{t-\tau}\right)-\sum_{i \in X} s_{i t-\tau}\left(p_{i t-\tau}-P_{t-\tau}\right)
\end{aligned}
$$

The first term and second terms are once again referred to as the within-firm component and the between-firm component. The third term is the covariance term in shares and productivity across continuing firms. The last two terms are taken to represent the contribution of firm turnover (entering and exiting firms).

The between-firm and firm-turnover components involve a comparison with productivity of an average firm. Continuing firms with increasing shares are said to contribute positively to aggregate productivity if they are more productive than an average firm in the base year. Entering firms are said to contribute positively to aggregate productivity if their productivity in the end year exceeds that of an 
average firm in the base year. For exiting firms, the contribution is said to be positive if they are less productive than an average firm in the base year.

The GR and the FHK methods differ in terms of the degree of disaggregation. FHK essentially provide a richer set of terms that allows us to examine more than one type of change. The GR decomposition can only tell whether there is a contribution made by firms that are on average more productive because they increase their employment share. The FHK decomposition not only tells us whether the more productive firms as of the first period gain employment share but whether those firms who increase their productivity also increase employment.

However, the additional detail comes at a cost. First, as discussed in Foster et al. (1998), the FHK method will be sensitive to measurement errors in outputs and inputs. ${ }^{3}$ For example, measurement errors in employment yield negative covariance between labour productivity and employment shares across firms as an upward (downward) bias in employment estimates generates downward (upward) bias in labour productivity estimates. Consequently, a negative covariance term in the FHK method might reflect a spurious correlation between changes in productivity and employment shares.

As a related point, the FHK method may suffer from "regression to mean" associated with transitory changes in employment and output. On average, firms with large initial employment and output are more likely to have experienced transitory increases in employment and output during a recent period. These firms are in turn more likely to experience declines as transitory changes reverse themselves. The use of initial employment shares and initial productivity levels in the FHK method inappropriately attributes transitory changes related to "regression to mean" to within-firm, between-firm and cross components. ${ }^{4}$ However, the importance of this point is a function of the time period chosen; if the decomposition formula is applied on a year-to-year basis, stochastic regression to the mean is more likely to be a "problem" than it is when it is measured over longer periods.

The FHK and GR methods compare the entering and exiting firms with an average firm in the industry in measuring the contribution of firm turnover to productivity growth. Baldwin (1995) argues that entering firms essentially replace exiting firms. To properly account for the contribution of firm turnover, he suggests that it is more appropriate to compare productivity between entering and exiting firms. This can be done within the spirit of either the FHK or GR methods. In the first case, we replace the average productivity of an industry with that of exiters in the FHK method (referred to here as Baldwin 1):

(16) $\Delta P_{t}=\sum_{i \in C} s_{i t-\tau} \Delta p_{i t}+\sum_{i \in C}\left(p_{i t-\tau}-P_{X t-\tau}\right) \Delta s_{i t}+\sum_{i \in C} \Delta s_{i t} \Delta p_{i t}$

$$
+\sum_{i \in N} s_{i t}\left(p_{i t}-P_{X t-\tau}\right)-\sum_{i \in X} s_{i t-\tau}\left(p_{i t-\tau}-P_{X t-\tau}\right)
$$

where $P_{X t-\tau}$ is the weighted average labour productivity of exiting firms in the base year. As the last term in Equation 3 equals zero, the above equation can be simplified to:

3. Microeconomic data files, especially those from administrative sources, often contain errors that are not corrected by the editing and imputation procedures used to produce accurate aggregate totals from these files.

4. Davis et al. (1996) discussed the "regression to mean" bias in many studies on size-growth relationship. 


$$
\begin{aligned}
\Delta P_{t} & =\sum_{i \in C} s_{i t-\tau} \Delta p_{i t}+\sum_{i \in C}\left(p_{i t-\tau}-P_{X t-\tau}\right) \Delta s_{i t}+\sum_{i \in C} \Delta s_{i t} \Delta p_{i t} \\
& +\sum_{i \in N} s_{i t}\left(p_{i t}-P_{X t-\tau}\right)
\end{aligned}
$$

The first three terms represent the contributions of continuing firms including within-firm effect, between-firm effect, and a co-variance term. The last term will be considered here as a measure of the contribution of firm turnover to aggregate productivity. ${ }^{5}$

The second version (referred to here as Baldwin 2) replaces the industry average productivity with the exiters' average productivity in the GR method:

$$
\text { (18) } \begin{aligned}
\Delta P_{t} & =\sum_{i \in C} \bar{s}_{i} \Delta p_{i t}+\sum_{i \in C}\left(\bar{p}_{i}-P_{X t-\tau}\right) \Delta s_{i t} \\
& +\sum_{i \in N} s_{i t}\left(p_{i t}-P_{X t-\tau}\right) .
\end{aligned}
$$

The three terms in the decomposition measure the contributions due to within-firm growth, betweenfirm compositional shifts and firm turnover.

\section{Interpretation of productivity decompositions}

The mechanical decompositions described in the previous section have been used to estimate the effect of various events - restructuring in the continuing-firm sector, entry, and exit. While some of the terms have a certain intuitive appeal, not all do. In particular, the way in which the effects of entry and exit are calculated is, as we argue below, problematic. The mechanical decompositions are not based on very credible assumptions about the dynamics of firms. In what follows, we attempt to rectify this.

How can we decide on the measure to use to estimate the effect of entry? To decide on the appropriate measure, we need to develop a counterfactual - to specify what would have happened in the absence of entry. To do so, let us start by rewriting the productivity difference between two periods:

19) $\Delta P_{t, t-\tau}=\left(\sum_{i \in C} s_{i t} p_{i t}-\sum_{i \in C} s_{i t-\tau} p_{i t-\tau}\right)+\left(\sum_{i \in E} s_{i t} p_{i t}-\sum_{i \in X} s_{i t-\tau} p_{i t-\tau}\right)$

There are two limiting assumptions that can be made in developing the counterfactual.

In the first case, let us assume that without entry, exit would have occurred anyway and we would only have been left with incumbents in the second period. Entry in this scenario then does not affect the rate of exit of existing firms or their productivity. It only affects the market share of existing firms, who end up smaller than otherwise because entrants capture part of the market share that they otherwise would have obtained. Then productivity growth that would have occurred in the absence of entry is:

20) $\Delta P_{t, t-\tau}=\left(\sum_{i \in C} \tilde{s}_{i t} p_{i t}-\sum_{i \in C} s_{i t-\tau} p_{i t-\tau}\right)-\sum_{i \in X} s_{i t-\tau} p_{i t-\tau}$, where $\tilde{s}_{\mathrm{i}}$ is the share that incumbents would have in the absence of entrants

Then, subtracting Equation 20 from Equation 19 gives an expression for the effect of entry:

5. The term is identical to the first term of Equation 9-2 in Baldwin (1995). 
21) $\Delta P_{t, t-\tau(\text { entry })=} \sum_{i \in E} s_{i t} p_{i t}-\sum_{i \in C}\left(\tilde{s}_{i t}-s_{i t}\right) p_{i t}$

Adding and subtracting $\sum_{i \in E} s_{i t} \bar{P}_{c t}$ produces:

22) $\Delta P_{t, t-\tau(e n t r y)}=\sum_{i \in E} s_{i t}\left(p_{i t}-\overline{P_{c t}}\right)$

where $\left.\bar{P}_{c t}=\sum_{i \in C}\left(\tilde{s}_{i t}-s_{i t}\right) / k\right) p_{i t}$, which is a weighted average of productivity of continuers in the second period, and $k=\sum_{i \in E} s_{i t}$.

This expression is just the share of entrants multiplied by the difference in productivity of the average entrant and the average firm. However, the average that should be used for this exercise is the weighted average of incumbents where the weights are the increase in shares that would have occurred without entry. In the absence of this information, using existing shares assumes that the increases would have been proportional to existing shares for all continuers. As the expression in Equation 21 demonstrates, when the average entrant is less productive than the average incumbent, this term will generally be negative.

A similar exercise for exits yields a formula identical to that for entrants - except that the effect is calculated relative to the productivity of existing firms in the first period. Once more, the counterfactual would have to assume that in the absence of exits, continuing firms would simply have picked up the slack. Then the effect of exits is simply the difference between the productivity of existing firms and exits, which is usually positive, weighted by the share of the exiting firms.

There is a second way in which we can approach the counterfactual. We can postulate that in the absence of entry, the firms that would have exited would have remained in the industry, that their market share in total is just that which entrants together captured, and that their productivity would have remained at the old levels. This is equivalent to arguing that there is no exogenous productivity gain that should be expected of exits, and entrants in effect drive out exits. In this case, productivity growth would have been:

23) $\Delta P_{t, t-\tau}=\left(\sum_{i \in C} s_{i t} p_{i t}-\sum_{i \in C} s_{i t-\tau} p_{i t-\tau}\right)+\left(\sum_{i \in X} \tilde{s}_{i t} p_{i t-\tau}-\sum_{i \in X} s_{i t-\tau} p_{i t-\tau}\right)$

where $\tilde{s}_{i t}$ is the share that exits would have achieved at the end of the period without entrants. Then subtracting Equation 23 - the productivity growth expected if this counterfactual were true - from the actual productivity growth in Equation 19 yields the following expression for the effect of entry:

24) $\Delta P_{t, t-\tau(\text { entry })}=\left(\sum_{i \in E} s_{i t} p_{i t}-\sum_{i \in X} s_{i t-\tau} p_{i t-\tau}\right)-\left(\sum_{i \in X} \tilde{s}_{i t-\tau} p_{i t-\tau}-\sum_{i \in X} s_{i t-\tau} p_{i t-\tau}\right)$, which reduces to:

25) $\Delta P_{t, t-\tau(\text { entry })}=\left(\sum_{i \in E} s_{i t} p_{i t}-\sum_{i \in X} \tilde{s}_{i t-\tau} p_{i t-\tau}\right)$

We add and subtract $\sum_{i \in E} s_{i t} \bar{P}_{x t-\tau}$, where $\bar{P}_{x t-\tau}=\sum_{i \in X} \frac{1}{k} s_{i t-\tau} p_{i t-\tau}$ is the average productivity of exits and $k=\sum_{i \in E} s_{i t}$. This yields:

26) $\Delta P_{t, t-\tau(\text { entry })}=\left(\sum_{i \in E} s_{i t}\left(p_{i t}-\bar{P}_{x t-\tau)}\right)\right.$ 


\section{DSTI/DOC(2002)2}

This is just the term that is used in the Baldwin decomposition.

In summary, the measures of the effect of entry outlined in the previous section contain implicit assumptions about the way in which entry affects industry productivity. There are two questions that need to be answered before the appropriate measure can be agreed upon. First, from whom do entrants take away market share? Hazledine's (1985) and Griliches' method (1995) implicitly assumed that entrants take away market share from the average incumbent who is more productive than the average entrant. Not surprisingly, using this implicit assumption, they concluded that entry had a deleterious effect on overall productivity.

As a general rule, this assumption is inappropriate. Small new firms are not likely to replace larger firms in most situations. New firms are smaller than the average incumbents, they pay lower wages and are less productive (Baldwin and Rafiquzzaman, 1995). Competition takes place within subgroups of an industry (Neuman, 1978). Small firms are more likely to compete against small firms. In doing so, entrants are most likely to displace exits. The evidence supporting this view is that the rate of entry and exit is closely related across industries (Cable and Schwalbach, 1991). Baldwin and Gorecki (1991) more carefully examine this proposition and find that, while entrants occasionally take share away from some incumbents who are even less productive than entrants, this is rare. Even when entrants take away share from the continuing population, they do not do so on a random basis. Baldwin (1995) demonstrated that, in these cases, entrants tend to take away share from continuers who are less productive than entrants. Therefore, weighted averages of incumbent productivity based on existing market shares in Equations 13 and 15 are generally inappropriate.

In what follows, we compare the results that are obtained from the GR, the FHK and the two Baldwin techniques to illustrate the magnitude of the differences produced by each. We focus primarily on the GR approach, not because we prefer it, but because the OECD in its most recent study of cross-country differences in the effect of turnover on productivity (OECD, 2001) has chosen this as its reference point.

The GR approach not only has the disadvantage that its implicit assumption about the effect of entry ignores the empirical evidence on entry. It also implicitly adopts a classification of incumbents that cannot come to grips with the more interesting facets of intra-industry competition. Internal change occurs within industries as firms trade market share. Some firms gain market share at the expense of others. However, those gaining market share do not necessarily gain employment share - especially in the large-firm market segment. Thus asking what the productivity gains are in the group that gains employment share will tell us little about what is happening in the group who are succeeding in the marketplace. Baldwin (1995) reported that in the 1970s, a substantial proportion of the total growth in productivity occurred as a result of this shifting of market share. Neither the FHK method nor the GR approaches capture this aspect of change. An accompanying paper will examine whether the importance of this component of incumbents arising from market share shifts that was observed in the 1970s has changed over the decades of the 1980s and 1990s.

\section{Data}

The data for our analysis comes from a longitudinal file developed from the Annual Surveys of Manufactures (ASM). The ASM covers the Canadian manufacturing sector. It collects information on shipments, value added, inventories and employment for about 35000 manufacturing plants in 1997 (for details, see Statistics Canada, 1979). The plants in the ASM are grouped to 236 manufacturing industries at the four-digit 1980 SIC (Standard Industrial Classification, 1980) level. We focus on the plant as a business unit, rather than the firm, because it allows finer distinctions to be made in calculating the contribution of various subsets of the population to productivity growth. 
The longitudinal file developed from the ASM follows manufacturing plants over the 1973-97 period. Each plant in the file has a unique code that allows us to identify entering, exiting and continuing plants. In addition, a plant is assigned a unique firm number and thus plants can be classified as belonging to a firm that continues over time, or to a multi-establishment or a foreign-controlled firm. As a result, the file can be used to estimate new plant entry rates and new firm entry rates of various types (see Baldwin et al., 2002). In this paper, we use the plant-based part of the file to define entry at the plant level. Entry is defined first as the arrival of new plants with employment in an industry, then is divided into those plants that are foreign- as opposed to domestic-controlled. Finally, plant entry is divided into those that are associated with single-plant firms and those that are associated with a multi-plant firm. The former arise from the entry of new firms; the latter are generally associated with the entry of firms from other industries and with new plant openings of firms that have already one plant in the industry concerned.

In this paper, we measure labour productivity of a plant as real gross output per worker. ${ }^{6}$ This is done primarily to allow comparability to the OECD cross-country study. Real gross output is measured as shipments plus net inventory changes, deflated by a gross output deflator at the four-digit level for the industry in which the plant is classified.

We examine entry and productivity change over three periods: 1973-79, 1979-88 and 1988-97. These periods are chosen to give us broad comparability in terms of growth across the business cycle. Each period spans a growth period and allows us to measure the effect of entry over a long enough time period to average out inconsistencies that arise in the file. In both the middle 1970s and the early 1990s, the frame that was used for the manufacturing file fell behind the population, and annual estimates of entry are biased downwards unless corrections are made for this. By 1979 and 1997, improvements had been made in the population used for the survey, returning it to the norms regularly used.

The three periods resemble one another in terms of the rates of growth of labour productivity (Baldwin et al., 2001), but they differ in one major respect. The first two are characterised by slow but continuous declines in tariffs as a result of the Kennedy and Tokyo round of tariff cuts. The 1990s, however, are categorised by the implementation of the Free Trade Agreement (FTA) with the United States and then the North American Free Trade Agreement (NAFTA).

\section{Plant turnover}

In this section, we present evidence on plant turnover and productivity growth for all of the manufacturing sector over the three periods that are broadly representative of the 1970s, the 1980s and the 1990s. As such, we are able to observe whether changes have occurred over the last three decades in turnover rates and their influence on the growth in labour productivity.

\subsection{Plant turnover and productivity differentials among entering, exiting and continuing plants}

Plant turnover has been important in Canadian manufacturing over the last three decades (Table 1). Some 39\% of the manufacturing plants in 1997 are new plants that entered over the 1988-97 period. Some 47\% of the manufacturing plants operating in 1988 were no longer operating in 1997.

6. Gross output is calculated as manufacturing shipments plus net changes in inventories of goods in processed and finished products. The number of workers includes both production and salaried workers. 
Table 1. Plant turnover and productivity differentials in total manufacturing

\begin{tabular}{|c|c|c|c|c|c|}
\hline & $\begin{array}{l}\text { Share of the no. } \\
\text { of plants }\end{array}$ & $\begin{array}{l}\text { Employment } \\
\text { share }\end{array}$ & Average size & $\begin{array}{c}\text { LP in the base } \\
\text { year }\end{array}$ & $\begin{array}{c}\text { LP in the end } \\
\text { year }\end{array}$ \\
\hline \multicolumn{6}{|l|}{ 1973-79 period } \\
\hline Entering plants & 38.53 & 12.09 & 17.30 & .. & 0.93 \\
\hline Exiting plants & 29.14 & 12.07 & 25.05 & 0.64 & .. \\
\hline Continuing plants & .. & .. & 75.05 & 1.00 & 1.11 \\
\hline \multicolumn{6}{|l|}{ 1979-88 period } \\
\hline Entering plants & 57.41 & 22.76 & 18.61 & .. & 0.80 \\
\hline Exiting plants & 47.10 & 20.70 & 24.22 & 0.73 &.. \\
\hline Continuing plants &.. &.. & 82.63 & 1.00 & 1.15 \\
\hline \multicolumn{6}{|l|}{ 1988-97 period } \\
\hline Entering plants & 38.77 & 20.83 & 27.41 &.. & 0.93 \\
\hline Exiting plants & 46.48 & 27.74 & 28.02 & 0.71 & .. \\
\hline Continuing plants & .. & .. & 63.39 & 1.00 & 1.27 \\
\hline
\end{tabular}

Entrants and exiters are on average much smaller than continuing plants, as reflected in the relatively smaller employment shares of entrants and exiters compared with the shares of the number of plants. Nevertheless, these shares are still large. Over 20\% of employment in 1997 was in plants that were new since 1988; $27 \%$ of employment in 1988 was in plants that closed by 1997.

After corrections are made for the fact that the three time periods are not exactly the same, turnover increases over the three periods. The sum of the entry and exit employment rates is about $4 \%$ when annualised during the $1970 \mathrm{~s}$. By the 1990s, it has climbed to over $5.4 \%$ - an increase of some $35 \%{ }^{7}$

Entry rates are broadly similar to exit rates, as has been previously reported for other countries (Geroski and Shwalbach, 1991). However, the 1990s differ from the earlier period in that exit rates, both in terms of number of plants closed and the proportion of total employment therein, increase relative to entry during this decade. ${ }^{8}$ This is symptomatic of a restructuring process that has accompanied the move to free North American Trade. Moreover, the average employment size of a new plant and a closed plant, when calculated relative to that of continuing plants, has increased quite dramatically during the 1990s.

What is most important for this study is the large productivity differential between entering and exiting plants. The average labour productivity of entering plants relative to incumbent plants at the end

7. We use the employment rather than the firm numbers rates for comparison purposes since they are less subject to change because of administrative practice associated with the survey.

8. This result can also be found in other databases that can be used to study the manufacturing sector. See Baldwin et al. (2002). 
year of each period is higher than exiting plants in the initial year of the period. ${ }^{9}$ For example, labour productivity of the 1988-97 entrants in 1997 was only $7 \%$ below that of continuing plants measured in 1988; while labour productivity of the 1988-97 plant closedowns was almost 30\% below that of continuing plants measured as of 1988. The large productivity differential between entering and exiting plants when combined with high turnover suggests that plant turnover is an important source of productivity growth in Canadian manufacturing.

It is noteworthy that this relative productivity difference has not shown any long-run trend upwards. The differences between entrants and exits was some 19 percentage points in the 1970s, declined to about 7 percentage points in the 1980s, and then returned to about 22 percentage points in the 1990s.

It is also important to note that even by the end of these longish periods, new plants were not more productive than the plants that continued throughout the period. It is difficult therefore to envisage an entry process in which the new plants supplant an "average" or representative continuing plant. The relative productivity of entrants and exits and the fact that their shares are similar, strongly suggests that competition occurs primarily between these two groups - at least over the time period examined here.

\subsection{Growth of entering plants}

The main factor that determines the contribution of plant turnover to productivity growth is the average productivity and size of entering plants in the end year. The larger and more productive the entering plants in the end year, the larger their contribution to productivity growth. In this section, we examine the growth of entering plants.

Previous studies show that entering plants are a heterogeneous group, some more productive and some less productive. Entering plants undergo both a selection and a learning process as competition culls out less productive plants and the survivors improve productivity (Baldwin and Rafiquzzaman, 1995; Aw, et al., 1997; Foster et al., 1998). Baldwin and Rafiquzzaman show that most of the improvement in an average entry cohort in the 1970s and 1980s comes from the culling process. In this section, we ask whether this is also the case for the 1990s.

To examine the roles of selection and learning, we focus on the plants that entered manufacturing between 1979 and 1988 and compare their survival and growth over the 1988-97 period to incumbents plants that did not enter between 1979-88 but were nevertheless operating in 1988. To do so, we regress the log of labour productivity, employment and output on a binary variable for the years 1988 and 1997 and binary variables to account for the difference between continuing plants and entrants. We also distinguish between incumbent plants as of 1988 that survive to 1997 and those that exit.

The results in Table 2 compare the various categories using the results of the regression analysis. In 1988, surviving entrants were $9 \%$ less productive and $70 \%$ smaller than incumbents who would survive. On the other hand, entrants who will fail over the period are $23 \%$ less productive than surviving incumbents and some $80 \%$ smaller. Figure 1 depicts the differences between the survivors and the exiters from the entrant population. These results indicate that the competitive process culls out the less productive and the smaller entrants. ${ }^{10}$

9. Average labour productivity in the table is weighted by employment at each plant and is expressed relative to the weighted average for continuing plants in the base year.

10. See Baldwin et al. (2000) for a more extensive statistical analysis of the characteristics of exiting new firms. 
Table 2. Comparing the survival and growth of plants that entered between 1979-88 (with the 1988 performance of continuing incumbents as the base)

\begin{tabular}{|c|c|c|c|}
\hline \multirow[b]{2}{*}{ Independent variables } & \multicolumn{3}{|c|}{ Dependent variables } \\
\hline & Labour productivity & Employment & Output \\
\hline \multicolumn{4}{|l|}{$\begin{array}{l}\text { Surviving members of the plants entered between 1979-88, } \\
\text { interacted with year binary variable for: }\end{array}$} \\
\hline 1988 & 91 & 30 & 28 \\
\hline 1997 & 108 & 44 & 48 \\
\hline Exiting members of the plants entered in between 1979-88 in 1988 & 77 & 21 & 16 \\
\hline \multicolumn{4}{|l|}{$\begin{array}{l}\text { Surviving members of the incumbent plants, interacted with year } \\
\text { binary variable for: }\end{array}$} \\
\hline 1988 & 100 & 100 & 100 \\
\hline 1997 & 122 & 91 & 112 \\
\hline Exiting members of the incumbent plants in 1988 & 91 & 64 & 58 \\
\hline
\end{tabular}

Learning can have two effects on entrants. On the one hand, it may allow them simply to improve their absolute productivity relative to their initial position. On the other hand, it may allow them to catch up with incumbents. To investigate the extent to which entrants learn after entry, we compare differences in growth between the surviving members of entering plants and incumbent plants (Figure 2). ${ }^{11}$

During the period, surviving entrants experience growth in both their productivity and their size. Their relative employment size moves from some $30 \%$ of the 1988 size of incumbents to $44 \%$ in 1997; their relative labour productivity increases from $91 \%$ to $108 \%$. Figure 2 translates this into relative growth rates and shows that the surviving members of entering plants do experience growth. During the 1988-97 period, labour productivity of the surviving entrants grew $1.9 \%$ per year, while employment and output grew by $4.2 \%$ and $6.1 \%$ per year. Employment and output growth, but not the labour productivity of the surviving entrants, exceeded the growth of surviving incumbents.

This indicates that there has been some learning taking place in the surviving plants of the original entry cohort. Their employment and output size increases and their growth rate in these two dimensions is just as rapid as that of incumbents; but the productivity of the surviving incumbents grew much faster moving them to about $122 \%$ of their original level by 1997 , while entrants just moved from $91 \%$ to $108 \%$ of the 1988 incumbent level over the same period.

Thus, the surviving members of entering plants experience slower labour productivity growth than the surviving members of incumbent plants. In effect, any catch up of an entry cohort to incumbents is accounted for by the culling of the less efficient plants in an entry cohort. Baldwin and Rafiquzzaman (1995) interpret this as evidence that learning is less important than selection in the productivity growth of entering plants in Canadian manufacturing. As Baldwin and Dhaliwal (2000) note, this may be because entrants focus more on product innovations that meet the growth in market demand than they do on process innovations.

11. $54 \%$ of the plants which entered between 1979-88 were no longer operating in 1997. 

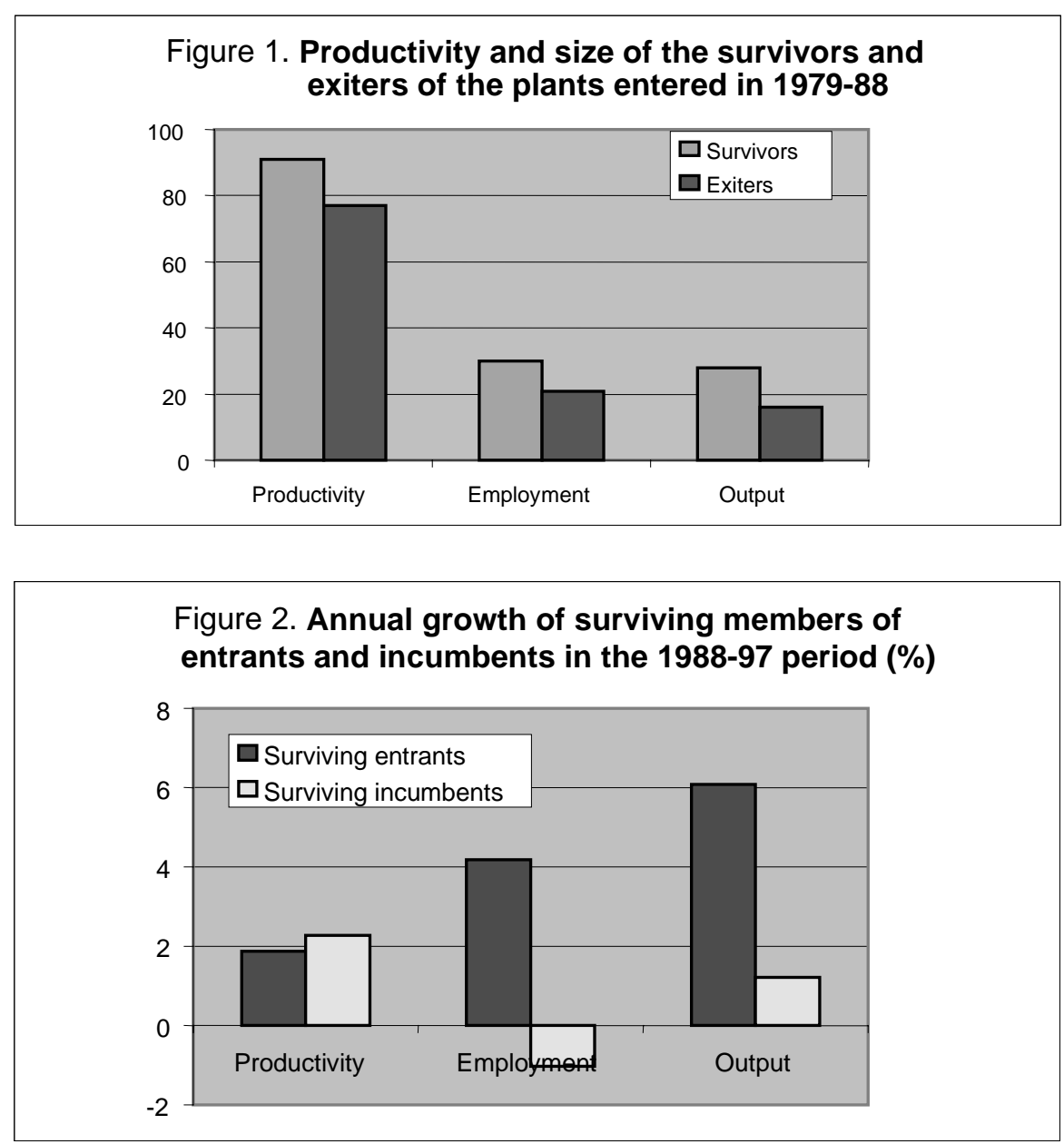

We also performed similar regressions for each of the 22 SIC two-digit manufacturing industries. ${ }^{12}$ Overall, the findings at the two-digit industry level are consistent with those for the total manufacturing sector. The members of an entering cohort that have lower productivity and that are smaller are more likely to fail. The surviving members of entering plants experience substantial growth in labour productivity, employment and output.

To conclude, new plants that manage to survive are considerably more productive than those who fail. They also become more productive than incumbents who fail. They are not more productive than the average incumbent and they are, therefore, unlikely to have gained market share from this group on average. Productivity decompositions that fail to recognise this fact will produce misleading estimates of the contribution of entry to the productivity process.

12. The results are available upon request from the authors. 


\section{Plant turnover and productivity growth}

\subsection{Aggregate}

The contribution of plant turnover to productivity growth in aggregate manufacturing is measured by applying the four separate decompositions outlined in Section 2 at the four-digit level (Table 3). ${ }^{13}$ These four-digit results are then aggregated, using average industry employment shares as weights. ${ }^{14}$

Table 3. Productivity decomposition in total manufacturing

\begin{tabular}{|c|c|c|c|c|c|c|c|}
\hline & LP growth & Within-plant & Between-plant & Cross-plant & Net entry & Entry & Exit \\
\hline \multicolumn{8}{|l|}{ FHK } \\
\hline $1973-79$ & 2.15 & 77.39 & 68.26 & -70.67 & 25.03 & 10.94 & 14.09 \\
\hline 1979-88 & 1.41 & 101.79 & 16.01 & -37.57 & 19.77 & 10.68 & 9.08 \\
\hline 1988-97 & 2.91 & 98.05 & 9.38 & -22.02 & 14.59 & 8.87 & 5.71 \\
\hline \multicolumn{8}{|l|}{ GR } \\
\hline $1973-79$ & 2.15 & 42.03 & 32.73 & -- & 25.24 & 5.61 & 19.63 \\
\hline 1979-88 & 1.41 & 83.04 & -1.88 & -- & 18.84 & 3.34 & 15.50 \\
\hline $1988-97$ & 2.91 & 86.97 & -5.24 & -- & 18.27 & 1.00 & $17.2 \varepsilon$ \\
\hline \multicolumn{8}{|c|}{ Baldwin v1 } \\
\hline $1973-79$ & 2.15 & 77.50 & 68.56 & -70.77 & 24.71 & -- & -- \\
\hline 1979-88 & 1.41 & 101.75 & 15.98 & -37.56 & 19.83 & -- & -- \\
\hline 1988-97 & 2.91 & 98.08 & 9.72 & -22.03 & 14.23 & -- & -- \\
\hline \multicolumn{8}{|c|}{ Baldwin v1 } \\
\hline $1973-79$ & 2.15 & 42.11 & 33.17 & -- & 24.71 & -- & -- \\
\hline $1979-88$ & 1.41 & 82.97 & -2.80 & -- & 19.83 & -- & -- \\
\hline 1988-97 & 2.91 & 87.07 & -1.30 & -- & 14.23 & -- & -- \\
\hline
\end{tabular}

The results from all four decomposition methods show that productivity growth within continuing plants is the predominant source of labour productivity growth in Canadian manufacturing. Moreover, most of this comes from the within-plant component. The contribution of the within-plant component ranges from $40 \%$ to $100 \%$ of aggregate productivity growth.

The component that measures the effect of compositional changes arising from shifts in employment shares among continuing plants plays a negligible-to-modest role in aggregate productivity growth after 1979. However, the compositional shift of employment towards more productive plants is an important source of productivity growth before 1979 , accounting for $30-70 \%$ of labour productivity growth in the 1973-79 period.

13. Table 3 uses gross output per worker, a measure of labour productivity. Table 1 in the appendix presents decomposition results using value added per worker and shows similar results.

14. The employment shares are averaged over the base and end years of each period. 
Plant turnover is an important source of productivity growth as more productive entrants replace exiting plants that are less productive. Both the GR and FHK methods can be compared to the Baldwin decomposition by summing the effect of entry and exit separately. When this is done, the different approaches yield similar conclusions.

The measured impact of total plant turnover does not appear to be very sensitive to the methods used. Plant turnover contributes a quarter of productivity growth in the 1973-79 period, 20\% in the 1979-88 period, and $15-20 \%$ in the $1988-97$ period.

It is noteworthy that the contribution of entry and exit jointly has declined over time. Despite the increase in plant turnover, the Canadian economy has therefore seen the contribution to productivity growth by plant turnover fall over the last three decades.

The FHK and GR methods further decompose the contribution of plant turnover into that from entering plants and that from exiting plants - although, as we have argued, both use implicit assumptions about the competitive process that are not applicable to Canadian circumstances. While the two methods yield similar estimates of the contribution of plant turnover, it should be noted that they provide very different estimates of the relative importance of entry $v s$. exit. The FHK decomposition shows that entering and exiting plants make similar contributions to productivity growth. In contrast, the GR method suggests that most of the contribution from plant turnover comes from exiting plants. The difference derives from the fact that FHK compare entrants to average productivity in the beginning of the period while GR compare it to average productivity over the entire period. This decreases the effect of entry using the GR method, which essentially assumes that replacement is occurring not of an average plant at the beginning of the period but the average plant somewhere in the middle of the period.

Fourth, the GR and the FHK methods yield quite different estimates of the contribution of within - as opposed to between - plant productivity growth. The FHK method suggests that the continuing plant population contributes large within-plant-growth - but that this is generally offset by a negative contribution from employment reallocation across plants. In particular, the cross-variance component in the FHK decomposition that catches the relationship between changes in labour productivity and employment share is negative and large. The GR method produces much smaller estimates of within-plant productivity growth.

To better explain the nature of the growth process that is taking place in the continuing population, we calculate correlations ${ }^{15}$ of labour productivity growth, output growth, employment growth, and initial labour productivity and employment levels across continuing plants for the 1988-97 period - Table 4. ${ }^{16}$ The correlations show a pattern that has been reported elsewhere (Baldwin, 1995; Baldwin et al., 1995; Baldwin and Sabourin, 2002). First, there is virtually no correlation between output growth and initial labour productivity growth. That is, if we divide the population of plants into two groups based on initial labour productivity at the beginning of the period, we cannot predict future growth in market share or in labour productivity.

Second, some plants do, however, grow larger than others and these plants also increase their share of employment - there is a positive correlation between output and labour growth. Those plants that are increasing market share are also growing their labour productivity more quickly - there is a positive correlation between output growth and labour productivity growth. This correlation can arise in one of two ways. First, labour productivity growth may improve efficiency, allow a plant to reduce its relative price and allow it to increase its market share. Second, increasing market share may increase profitability and

15. Correlation matrices are calculated using employment in the base year as weights.

16. The correlation matrices for the other two periods are similar. 
lead to more investment, thereby increasing labour productivity. In any case, there is a substantial shifting of relative position associated with changes in relative productivity. However, these shifts are not reflected in concomitant shifts in employment share. Labour productivity growth is negatively correlated with employment growth. Those plants that expand market share also increase employment, but there must be enough other plants also increasing employment - those losing market share - that the overall relationship between employment share and labour productivity is negative. It is this negative covariance term that shows up in the FHK decomposition of plant productivity growth.

Table 4. Correlation of productivity, output and employment among continuing plants, 1988-97

\begin{tabular}{|c|c|c|c|c|c|}
\hline & LP growth & Output growth & Labour & Initial LP & Initial labour \\
\hline LP growth & 1 & & & & \\
\hline Output growth & $0.49^{*}$ & 1 & & & \\
\hline Labour growth & $-0.22^{*}$ & $0.74^{*}$ & 1 & & \\
\hline Initial LP & $-0.04^{*}$ & $-0.02^{*}$ & 0.01 & 1 & \\
\hline Initial labour & $0.17^{*}$ & $-0.03^{*}$ & $-0.17^{\star}$ & $0.21^{*}$ & 1 \\
\hline
\end{tabular}

Despite the differences in the levels of the GR and FHK methods, there is one common finding. In both cases, the within-plant component increases over time. This suggests that the net effect of reallocation of labour has become less important over time in Canada.

For the rest of the paper, we report the results using the GR method since this gives us comparability to the published OECD results. We note that the net effect of entry and exit that this technique produces is close to that produced by the Baldwin method.

\subsection{Plant turnover among foreign-controlled vs. domestic-controlled plants}

Foreign-controlled plants contributed about 50\% of manufacturing output in 1997. They are perceived to transmit new production techniques and business practices from abroad and are an important source of productivity growth (Globerman, 1999). Baldwin and Dhaliwal (2000) report that the average labour productivity of multinationals is higher than for domestic plants and that it has been growing over the last two decades. In this section, we focus on the contribution that plant turnover among foreign-controlled plants makes to productivity growth.

The shares of entrants, exiters and continuers accounted for by foreign $v s$. domestic plants, along with their relative productivity are presented in Table 5. Foreign-controlled continuing plants are more productive than domestic-controlled continuing plants, and the gap is widening. Foreign-controlled continuing plants are $70 \%$ more productive than domestic-controlled ones in 1988, but they are $110 \%$ more productive in 1997 - an increase of some 40 percentage points. In the 1980s, they increased their relative productivity by about 20 percentage points. There was virtually no change in the 1970s in their relative labour productivity advantage. 
DSTI/DOC(2002)2

Table 5. Plant turnover and productivity differentials in total manufacturing, foreign- vs. domestic-controlled plants

\begin{tabular}{|c|c|c|c|c|c|c|c|}
\hline & & Share of the no. of plants & Employment share & Output share & $\begin{array}{c}\text { LP in the base year } \\
\text { relative to } \\
\text { continuers base } \\
\text { year }\end{array}$ & $\begin{array}{l}\text { LP in the end year } \\
\text { relative to } \\
\text { continuers base } \\
\text { year }\end{array}$ & $\begin{array}{l}\text { LP in the end year } \\
\text { relative to } \\
\text { continuers end } \\
\text { year }\end{array}$ \\
\hline \multicolumn{8}{|c|}{ 1973-79 period } \\
\hline \multirow[t]{2}{*}{ Entering plant } & Domestic & 94.67 & 77.88 & 68.72 & & 0.82 & 0.74 \\
\hline & Foreign & 5.33 & 22.12 & 31.28 & & 1.31 & 1.18 \\
\hline \multirow[t]{2}{*}{ Exiting plant } & Domestic & 91.70 & 70.57 & 64.91 & 0.59 & & \\
\hline & Foreign & 8.30 & 29.43 & 35.09 & 0.76 & & \\
\hline \multirow[t]{3}{*}{ Continuing plant } & Domestic & 83.42 & 58.70 & 47.50 & 0.81 & 0.90 & 0.81 \\
\hline & Foreign & 16.58 & 41.30 & 52.50 & 1.27 & 1.44 & 1.29 \\
\hline & All & & & & 1.00 & 1.11 & 1.00 \\
\hline \multicolumn{8}{|c|}{ 1979-88 period } \\
\hline \multirow[t]{2}{*}{ Entering plant } & Domestic & 95.75 & 84.61 & 73.22 & & 0.69 & 0.60 \\
\hline & Foreign & 4.25 & 15.39 & 26.78 & & 1.39 & 1.21 \\
\hline \multirow[t]{2}{*}{ Exiting plant } & Domestic & 92.37 & 73.09 & 60.04 & 0.60 & & \\
\hline & Foreign & 7.63 & 26.91 & 39.96 & 1.08 & & \\
\hline \multirow[t]{3}{*}{ Continuing plant } & Domestic & 83.83 & 61.66 & 52.43 & 0.85 & 0.93 & 0.81 \\
\hline & Foreign & 16.17 & 38.34 & 47.57 & 1.24 & 1.53 & 1.33 \\
\hline & All & & & & 1.00 & 1.15 & 1.00 \\
\hline \multicolumn{8}{|c|}{ 1988-97 period } \\
\hline \multirow[t]{2}{*}{ Entering plant } & Domestic & 93.98 & 79.65 & 60.47 & & 0.70 & 0.55 \\
\hline & Foreign & 6.02 & 20.35 & 39.53 & & 1.80 & 1.42 \\
\hline \multirow[t]{2}{*}{ Exiting plant } & Domestic & 92.31 & 72.08 & 60.46 & 0.59 & & \\
\hline & Foreign & 7.69 & 27.92 & 39.54 & 1.00 & & \\
\hline \multirow[t]{3}{*}{ Continuing plant } & Domestic & 87.46 & 63.04 & 49.96 & 0.79 & 0.93 & 0.73 \\
\hline & Foreign & 12.54 & 36.96 & 50.04 & 1.35 & 1.94 & 1.53 \\
\hline & All & & & & 1.00 & 1.27 & 1.00 \\
\hline
\end{tabular}


An important fraction of the employment and output affected by plant turnover is due to foreigncontrolled firms opening up and closing down plants. Over the 1988-97 period, foreign-controlled entering plants accounted for $6 \%$ of new plants, but $20 \%$ of employment and $40 \%$ of output of all entrants (Figure 3). Foreign-controlled exiting plants accounted for $8 \%$ of exiting plants, but $28 \%$ of employment of all exiters and $40 \%$ of output.

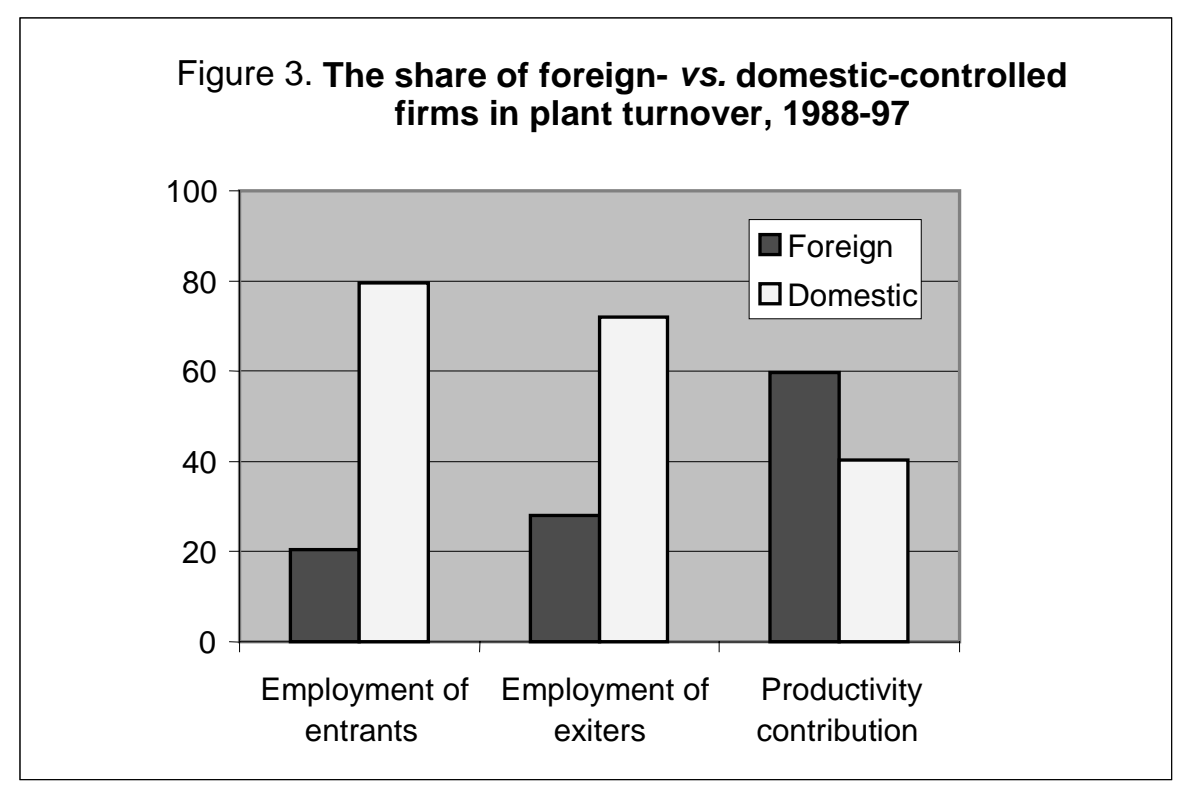

Trade liberalisation has increased dramatically in the 1990s, as has the importance of foreign entrants - from $26 \%$ in the 1970 s to $40 \%$ in the 1990s. On the other hand, their share of employment has remained virtually constant $-22 \%, 15 \%$, and $20 \%$ in the three decades.

Foreign entrants and exits are more productive than their domestic counterparts. Moreover, their productivity has increased relative to domestic entrants over this period. Figure 4 plots the relative productivity of foreign entrants compared to domestic entrants over the three periods. Starting at 1.6 times domestic entrants in the 1970s, the relative productivity had increased to 2.6 times that of domestic entrants by the 1990s. Foreign exits also were more productive than domestic exits, but here there is not a continuous upward trend.

Over the 1980s and 1990s, there has been a shift in employment to small domestic plants. This group is less productive (Baldwin, 1996). The increasing productivity of foreign entrants may therefore be the result almost entirely of reductions in the productivity of domestic rather than the increase in the productivity of foreign entrants. To examine this possibility, we measure the productivity of foreign entrants not against domestic entrants but against the population of continuers.

The productivity of foreign entrants calculated relative to the end-year population of continuers has increased dramatically over time - from 1.18 in 1979 to 1.33 in 1988 to 1.53 in 1997 (Table 5). The trade liberalisation adjustments that have been taking place over the last quarter century have involved the opening of foreign-controlled plants that are increasingly productive relative to the population as a whole. Nevertheless, part of this may just be the result of domestic plants becoming less productive. When we compare the relative productivity of foreign entrants to that of the continuing foreign population (Figure 6), we see that the relative productivity of both groups has grown at about the same pace. The increasing productivity of foreign entrants reflects the overall improvement in the foreign sector. 

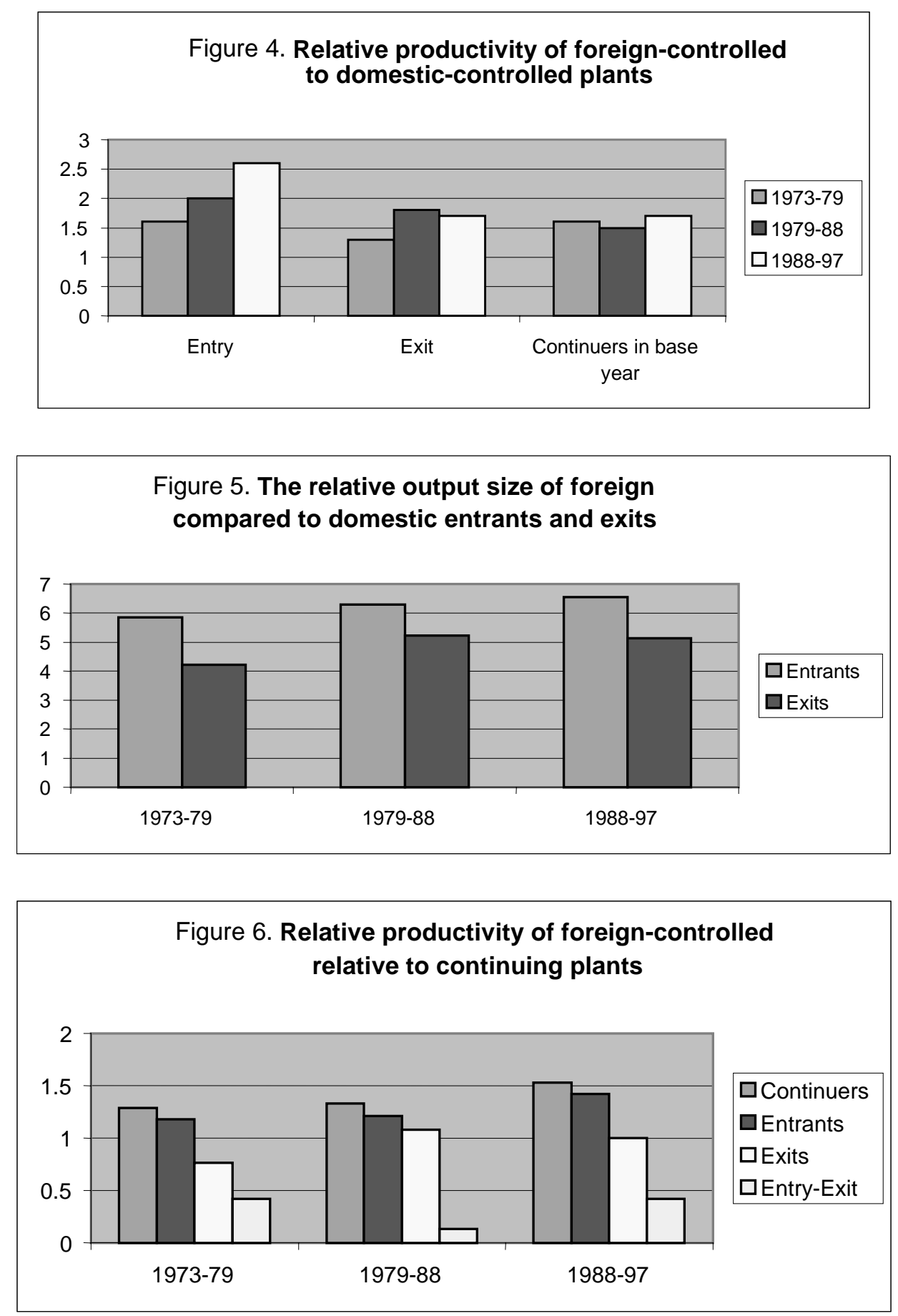

Foreign-controlled entrants and exiters are much larger than domestic-controlled ones. Figure 5 depicts the relative size of entrants - calculated as the relative output share divided by their relative plant share over the three periods. This difference has increased steadily over the three time periods, as has has the relative size of plants that were being closed. However, the difference between the two has widened in the 1990s relative to the 1980s. Restructuring associated with the dramatic trade liberalisation of the 1990s has led the foreign-sector to close down smaller plants than it opened. 


\section{DSTI/DOC(2002)2}

The productivity of foreign entering plants is considerably greater than the productivity of foreign exiting plants. The relative position of these two groups compared to continuing plants is depicted in Figure 6 for each of the last three decades. The relative productivity of foreign entrants compared to continuing plants (taken in the terminal year of each period) has increased - as has the relative productivity of the continuing plant of foreign-controlled plants (also calculated in the terminal year of each period). The relative productivity of exits of foreign plants (calculated relative to initial year population) has decreased in the 1990s compared to the 1980s. Freer trade has seen the foreign sector begin to close increasingly less-productive plants. The difference between the productivity of new and closed plants has widened in the 1990s, although it has only returned to the levels found in the 1970s.

The productivity decompositions that divide plant into domestic and foreign-controlled are presented in Table 6 using the GR method. ${ }^{17}$ Plant turnover by foreign-controlled firms is an important source of productivity growth in Canadian manufacturing, as shown in Table 6. During the 1988-97 period, 12\% or 0.35 percentage points per year of the growth in labour productivity is due to foreign-controlled firms opening up and closing down plants. This contribution has been relatively constant over time. While entry and exit together have been less important to productivity growth in more recent decades, this is caused by the decline in the contribution made by the entry and exit of domestic plants.

Table 6. Productivity decomposition in total manufacturing

Domestic- vs. foreign-controlled plants: GR approach

\begin{tabular}{lccccc}
\hline Plants & Within-plant & Between-plant & Net entry & Entry & Exit \\
\hline $1973-79$ & & & & & \\
Domestic-controlled & 24.92 & 6.95 & 14.88 & 1.52 & 13.36 \\
Foreign-controlled & 16.07 & 25.31 & 11.88 & 4.77 & 7.11 \\
$1979-88$ & & & & & \\
Domestic-controlled & 29.07 & 0.17 & 8.12 & -2.45 & 10.57 \\
Foreign-controlled & 52.54 & -2.05 & 12.14 & 7.09 & 5.05 \\
1988-97 & & & & & \\
Domestic-controlled & 29.24 & -3.45 & 7.78 & -4.74 & 12.52 \\
Foreign-controlled & 56.55 & -1.64 & 11.52 & 6.81 & 4.71 \\
\hline
\end{tabular}

The contribution of foreign-controlled plant turnover is disproportionately large relative to their employment. As Figure 3 shows, over the 1988-97 period, foreign-controlled entrants account for $20 \%$ of employment of all entering plants and foreign-controlled exiters account for $28 \%$ of employment of all exiting plants. However, plant turnover of foreign controlled firms represents $60 \%$ of the contribution from total plant turnover. ${ }^{18}$

It is also noteworthy that the growth of the within-plant component is considerably higher in the foreign sector in the last two decades. It has risen from about $41 \%$ of the total in the 1970 s to over $55 \%$ of the total in the 1990s. At the same time, it has become increasingly concentrated in the within-plant segment; that is, it is caused by productivity growth holding shares constant, rather than shifts in employment share towards more productive plants. The latter was more important in the 1970s.

In summary, foreign-controlled plants have become increasingly important as a source of entry. They have become increasingly large relative to domestic entrants, and have become increasingly productive relative to both domestic entrants and incumbents. The latter increase was particularly large in the period

17. Table 6 uses gross output per worker as a measure of labour productivity. Table 2 in the appendix reports decomposition results using value added per worker and shows similar results.

18. The results for the 1973-79 and 1979-88 periods are similar. 
post-FTA and NAFTA. Finally, the contribution of foreign plant turnover from entry and exit relative to domestic turnover is large and growing over the period.

\subsection{Plant turnover among single-plant vs. multi-plant firms}

To this point, we have examined the effect of plant entry and exit. New plants may be associated with entirely new firms or with existing firms. New plants that are associated with the arrival of new firms are generally new plants associated with single-plant firms. ${ }^{19}$ New plants associated with multi-plant firms are either new plants of firms already in a particular industry, or are created by firms that are in other industries and fall into the experienced-entry category (de alio as opposed to de novo entry). Disney et al. (2000) find that, for the UK manufacturing sector over the 1980-92 period, much of the contribution of plant turnover to productivity growth is due to multi-plant firms starting up and closing down plants. In this section, we divide new plants into those owned by single-plant firms and those associated with multi-plant firms, and measure the contribution that plant turnover in each group makes to total productivity growth.

In 1997, multi-plant firms produced $75 \%$ of output and employed $60 \%$ of workers in Canadian manufacturing. The plants that are part of multi-plant firms accounted for $22 \%$ of all plants.

Plants opened up or closed down by multi-plant firms represent an important part of plant turnover in Canadian manufacturing (as shown in Table 7). The entrants and exiters of multi-plant firms account for $10-15 \%$ of the number of entrants or exiters in Canadian manufacturing, 35-50\% of employment and $50-70 \%$ of output. The extrants and exiters of multi-plant firms are much larger than the entrants and exiters of single-plant firms, as reflected in the higher employment or output shares of the entrants and exiters of multi-plant firms.

19. Except in the rare circumstances where a new firm enters by simultaneously building more than one plant in the same year. 
Table 7. Plant turnover and productivity differentials in total manufacturing, single- vs. multi-plant firms

\begin{tabular}{|c|c|c|c|c|c|c|c|}
\hline & & $\begin{array}{l}\text { Share of the } \\
\text { no. of plants }\end{array}$ & $\begin{array}{l}\text { Employment } \\
\text { share }\end{array}$ & Output share & $\begin{array}{l}\text { LP in the base year relative } \\
\text { to continuers base year }\end{array}$ & $\begin{array}{l}\text { LP in the end year relative } \\
\text { to continuers base year }\end{array}$ & $\begin{array}{l}\text { LP in the end year } \\
\text { relative to continuers end } \\
\text { year }\end{array}$ \\
\hline \multicolumn{8}{|c|}{ 1973-79 period } \\
\hline \multirow[t]{2}{*}{ Entering plant } & Single & 89.62 & 57.73 & 39.35 & & 0.63 & 0.57 \\
\hline & Multi & 10.38 & 42.27 & 60.65 & & 1.33 & 1.20 \\
\hline \multirow[t]{2}{*}{ Exiting plant } & Single & 83.80 & 47.44 & 39.17 & 0.53 & & \\
\hline & Multi & 16.20 & 52.56 & 60.83 & 0.74 & & \\
\hline \multirow[t]{3}{*}{ Continuing plant } & Single & 67.95 & 24.27 & 15.51 & 0.64 & 0.70 & 0.63 \\
\hline & Multi & 32.05 & 75.73 & 84.49 & 1.12 & 1.25 & 1.13 \\
\hline & All & & & & 1.00 & 1.11 & 1.00 \\
\hline \multicolumn{8}{|c|}{ 1979-88 period } \\
\hline \multirow[t]{2}{*}{ Entering plant } & Single & 90.10 & 66.67 & 47.96 & & 0.57 & 0.50 \\
\hline & Multi & 9.90 & 33.33 & 52.04 & & 1.25 & 1.09 \\
\hline \multirow[t]{2}{*}{ Exiting plant } & Single & 85.37 & 49.62 & 34.89 & 0.51 & & \\
\hline & Multi & 14.63 & 50.38 & 65.11 & 0.94 & & \\
\hline \multirow[t]{3}{*}{ Continuing plant } & Single & 65.19 & 22.31 & 13.96 & 0.63 & 0.68 & 0.59 \\
\hline & Multi & 34.81 & 77.69 & 86.04 & 1.11 & 1.33 & 1.16 \\
\hline & All & & & & 1.00 & 1.15 & 1.00 \\
\hline \multicolumn{8}{|c|}{ 1988-97 period } \\
\hline \multirow[t]{2}{*}{ Entering plant } & Single & 84.86 & 64.85 & 44.95 & & 0.64 & 0.50 \\
\hline & Multi & 15.14 & 35.15 & 55.05 & & 1.45 & 1.14 \\
\hline \multirow[t]{2}{*}{ Exiting plant } & Single & 84.05 & 47.71 & 32.35 & 0.48 & & \\
\hline & Multi & 15.95 & 52.29 & 67.65 & 0.92 & & \\
\hline \multirow[t]{3}{*}{ Continuing plant } & Single & 73.79 & 30.37 & 17.97 & 0.59 & 0.72 & 0.57 \\
\hline & Multi & 26.21 & 69.63 & 82.03 & 1.18 & 1.58 & 1.24 \\
\hline & All & & & & 1.00 & 1.27 & 1 \\
\hline
\end{tabular}

Note: The share of exiting plants reflects the share in the base year. The share of entering plants reflects the share in the end year.

The share of continuing plants is the share in the base year. 
The entering plants of multi-plant firms are more productive than the entering plants of single-plant firms. The plants belonging to multi-plant firms that entered in the 1988-97 period are more than twice as productive as those that belong to single-plant firms.

Table 7 also shows that continuing plants that are part of multi-plant firms are more productive than the plants that are part of single-plant firms - and the gap is widening. The percentage difference in labour productivity between them increased from 100\% in 1988 to $120 \%$ in 1997.

Comparison of the relative productivity of entrants and exits in multi-plant as opposed to single-plant firms indicates that there are substantial differences between the new and the closed plants in the first group, but not in the second, in most of the periods.

Almost all of the contribution of plant turnover to productivity growth is due to more productive new plants of multi-plant firms displacing exiting plants of these firms that are less productive (Table 8). Figure 7 shows that the net contribution from plant turnover of multi-plant firms is disproportionate relative to their employment share. The contribution of plant turnover due to multi-plant firms opening up or closing down plants exceeds their shares of employment.

Table 8. Productivity decomposition in total manufacturing Single- vs. multi-plant firms: GR approach

\begin{tabular}{lrrrrr}
\hline Plants & Within-plant & Between-plant & Net entry & Entry & Exit \\
\hline $1973-79$ & & & & & \\
Single-plant firm & -13.27 & 21.50 & 6.16 & -4.57 & 10.73 \\
Multi-plant firm & 54.19 & 11.06 & 20.36 & 10.51 & 9.85 \\
1979-88 & & & & & \\
Single-plant firm & 4.99 & -1.41 & 0.29 & -9.38 & 9.67 \\
Multi-plant firm & 77.55 & -0.50 & 19.07 & 12.68 & 6.39 \\
$1988-97$ & & & & & \\
Single-plant firm & 8.90 & -2.82 & 2.52 & -7.38 & 9.90 \\
Multi-plant firm & 77.55 & -2.40 & 16.25 & 8.52 & 7.73 \\
\hline
\end{tabular}

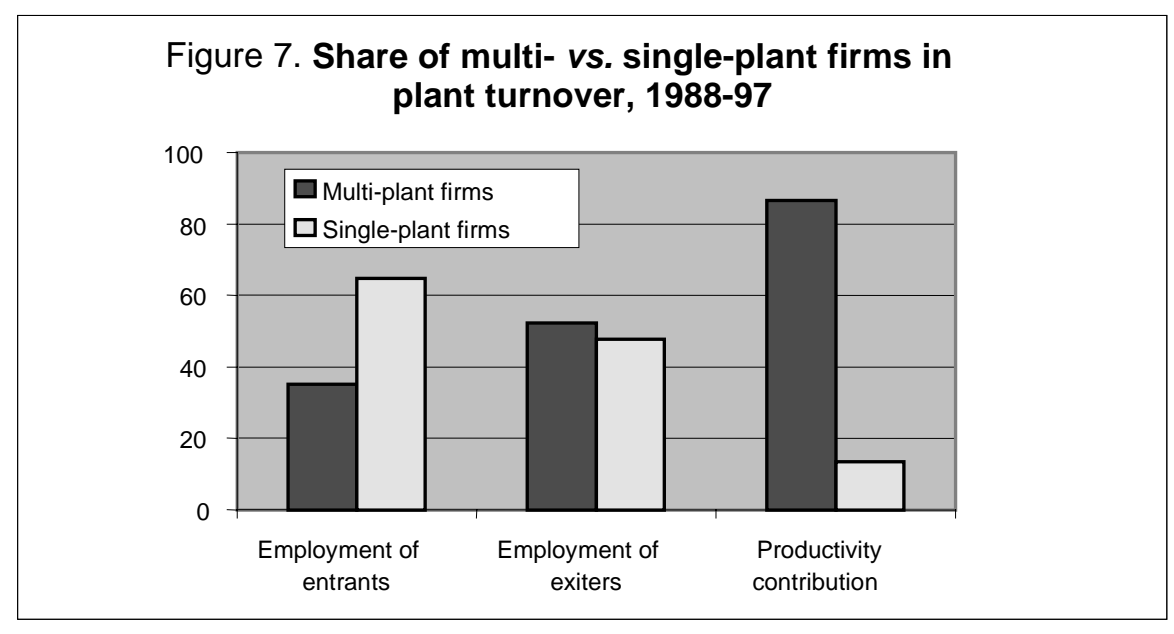

It is also noteworthy that the continuing plant contribution of multi-plant firms greatly exceeds that of single-plant firms (Table 8). A remarkable feature then of productivity growth in Canadian manufacturing is the predominant role of multi-plant firms. Multi-plant firms account for almost all of the productivity growth in Canadian manufacturing in the three periods examined. Multi-plant firms account for $85 \%$ of 
growth in labour productivity in the 1973-79 period and more than $90 \%$ of growth in the 1979-88 and 1988-97 periods. The contribution of multi-plant firms to productivity growth is much greater than their share of employment would suggest. ${ }^{20}$

\section{Plant turnover and productivity growth at industry-level manufacturing}

In previous sections, we have focused on the aggregate manufacturing sector when examining entry and exit and its contribution to productivity growth. The broad overview that this provides hides important differences at the industry level that serve to help us understand the forces that generate productivity growth.

In this section, we examine plant turnover and productivity growth in 22 manufacturing industries at the two-digit SIC level. Appendix Tables 3, 4 and 5 contain plant turnover and productivity for entering, exiting and continuing plants at the two-digit level over the 1973-79, 1979-88 and 1988-97 periods. At issue is the extent to which there are discernible patterns in the differences of turnover and productivity growth at the industry level and whether these differences are relatively constant or change over time.

If the differences are constant, this would indicate that basic structural differences (i.e. market structure) dominate explanations of the impact of entry and exit because these characteristics change very little over time. If the interindustry pattern changes considerably over time, then a changing macroeconomic environment associated with business cycles, changes in the trade environment or changes in technology which suddenly give entrants an advantage over incumbents and lead to more entry, are likely to play larger roles.

We also examine whether differences in plant turnover and its contribution to productivity growth are concentrated in more innovative industries. Plant turnover is often perceived to be more rapid and the contribution of plant turnover to productivity more important in the ICT-related industries. In order to test this proposition, we examine differences in plant turnover and productivity growth between the coremanufacturing sector that produces more innovations and the remaining industries in the manufacturing sector. ${ }^{21}$

\subsection{Patterns of entry and exit at the two-digit level}

Overall, the findings at the two-digit level are consistent with those for total manufacturing. First, a large amount of plant turnover takes place in all manufacturing industries. During the 1988-97 period, the number of entering plants calculated as a share of total number of plants ranges from a low of $22 \%$ in Tobacco to a high of 50\% in Refined petroleum and coal products. The share of exiting plants ranges from $26 \%$ in Tobacco to $64 \%$ in Clothing. Second, entering plants are more productive than exiting plants in most manufacturing industries.

The large amount of plant turnover, combined with productivity differentials between entering and exiting plants, have a positive and significant impact on productivity growth in almost all manufacturing industries, as shown in Appendix Tables 6,7 and 8. Plant turnover contributes positively to labour

20. Multi-plant firms account for 60-70\% of employment in aggregate manufacturing in the three periods.

21. There are other potential explanations for cross-industrial differences in plant turnover and productivity growth. The most important perhaps relates to entry and exit barriers including: openness to domestic and international competition as conditioned by trade barriers and industry regulation, capital and financing requirements of entry, and economies of scale. 
productivity in 21 of the 22 industries between 1973-79, in 18 of the 22 industries between 1979-88, and in 20 of the 22 industries between 1988-97. On average, the net entry component contributes 0.5 percentage points of the $2.2 \%$ annual growth in labour productivity in the 1973-79 period, 0.2 percentage points of the annual $1.4 \%$ growth in the $1979-88$, and 0.5 percentage points of the $2.7 \%$ annual growth in the $1988-97$ period.

While entry and exit make an important contribution to the total growth in productivity, it must nevertheless be recognised that it is not the most important component contributing to productivity growth. Moreover, overall productivity growth is not larger when the proportion that net entrants contribute is larger. The correlation between the proportion contributed by net entry and the average productivity growth rate in a particular period is negative: -0.29 for the $1970 \mathrm{~s},-0.01$ for the $1980 \mathrm{~s}$ and -0.08 for the 1990s. Entry is important - but we should not lose sight of the fact that it is not the dominant force driving productivity growth in an industry.

Nevertheless, the determinants of the interindustry differences in the contribution that net entry makes are still of interest. The importance of the net entry component depends upon the relative size of entrants (their employment share) and the difference between the relative productivity of entrants and exits.

To test the stability of the interindustry differences in entry and exit over time, we examine the correlations at the industry level across time. Here, there is substantial stability over adjacent time periods. Using employment shares, the correlation of industry entry rates between the 1970s and 1980s is 0.89; between the 1980s and 1990s, it is 0.85 . For exits, the correlations are 0.75 and 0.68 , respectively. Over a longer period, there is evidence of more change in interindustry differences since the correlation between the 1970 s and 1990 s for entry and exit falls to 0.76 and 0.62 , respectively.

The industry changes in entry and exit that occur over the two decades do not move continuously in the same direction. The correlation between the changes in employment entry rates between the 1970s and 1980 s with the changes between the 1980s and 1990s is -0.72. Industries that saw an increase in entry rates between the first and second periods saw less of an increase or a decline between the second and third periods. This is less true of employment exit rates where the same correlation was also negative but only -0.17 .

What is it that determines the relative importance of entry and exit in terms of market share? Here theories have concentrated on market structure such as barriers to entry, on the ease of post-entry growth, and on disequilibrium conditions associated with above-average profitability. This section is not intended to provide an exhaustive test of these alternatives but we do find that the conditions that allow entrants to become large compared to incumbents are closely related to the ultimate importance of turnover, as measured by employment share. The relative employment size of entrants and exits is strongly correlated with the employment share of entry and exit $(0.80,0.97$, and 0.96 for entry and $0.89,0.86$, and 0.86 for exit in the three respective periods).

The other variable that strongly influences the contribution made by the entry of new plants and the exit of old plants is the productivity of each group relative to continuers or relative to one another. This variable will be determined by the ability of new plants to adopt new technologies relative to existing firms. In turn, this will be a function of the extent to which new technologies are best introduced into a new environment, or the extent to which the new technologies are best combined with other technologies in existing plants.

To test the stability of the interindustry differences in relative labour productivity over time, we examine the correlations at the industry level across time periods. Here, there is much less stability over adjacent time periods than there was for entry and exit rates. The correlations of industry entrants' and 
exiters' relative productivity to continuers between the 1970 s and 1980 s are 0.18 and 0.27 , respectively. Over a longer period, there is evidence of more change in interindustry differences since the correlation between the 1970s and 1990s for entry and exit falls to -0.01 and 0.31 , respectively. For the $1980 \mathrm{~s}$ and $1990 \mathrm{~s}$, these correlations increase to 0.73 and 0.55 , respectively. If we examine the correlations in the difference in relative productivity between entrants and exits, the same pattern emerges. The correlation between the differences for the 1970s and 1980s is -0.22 and for the 1970s and 1990s, it is -0.30 . However, it is 0.78 between the 1980s and 1990s. The 1970s then appear to be quite different from the 1980s and 1990s. There are more similarities between the 1980s and 1990s.

Contrary to our earlier results for the relationship between average relative size of entrants and entry rates, there is very little correlation between average size and relative productivity. For entry, the correlations are $-0.33,0.01$ and 0.21 for the three time periods. Whatever allows entrants to obtain a relatively large stature compared to incumbents is not closely related to the underlying technological characteristics that allow new plants to have higher productivity than incumbents.

Do entry and exit contribute in the same proportion to productivity growth over time? The high correlations between employment entry and exit shares over time and the low correlations between the relative labour productivity of entrants results in virtually no connection between the contributions made by net entry at the industry level. These correlations are 0.001 between the 1970s and 1980s and -0.01 between the 1970s and 1990s. They are slightly higher, but still small (0.29), between the 1980s and 1990s.

This suggests that explanations of the importance of the contribution made by entry to productivity growth should focus on factors that change over time. In the next section, we examine one change that has occurred in the environment.

\subsection{Plant turnover and trade liberalisation}

What are the influences that may cause the interindustry entry pattern to change over time? They include changes in structural conditions like entry barriers, changing technologies, and major shifts in the environment.

Changes in trade are one exogenous environmental influence that may affect entry and exit. There is no unambiguous effect to be expected from increases in trade intensity. To the extent that an increase in imports reduces profitability, it should reduce entry and increase exit, while an increase in exports may reduce exit and increase entry for the opposite reason. More complex models yield ambiguous predictions about the effect of trade liberalisation: increases in trade may be accompanied by less entry if existing plants begin to exploit scale economies by internal expansion. Increases in two way intra-industry trade may be accompanied by specialisation that may require the building of new plants to handle a different product line. In this case, an increase in imports that is simultaneous with increases in exports will lead to more entry. In this section, we investigate the actual relationship that exists between plant turnover in the Canadian manufacturing sector and changes in trade patterns that have taken place.

Over the period under study, there have been dramatic changes in trade intensity (Table 9). Imports as a percentage of domestic disappearance ${ }^{22}$ have risen from $18 \%$ in 1973 to $39 \%$ in 1997 in an average twodigit industry. At the same time, export intensity has increased from $22 \%$ to $42 \%$. Some industries have become more export intensive; others have become more import intensive - but the net effect has been relatively small. The mean of the absolute differences between import and export intensity has gone up

22. Domestic disappearance is defined as imports plus domestic shipments minus exports. 
relatively little. Most of the time, there have been simultaneous increases in both imports and exports. The measure of intra-industry trade has more than doubled.

Table 9. Changes in trade intensity (average two-digit values)

\begin{tabular}{ccccc}
\hline & Import intensity & Export intensity & $\begin{array}{c}\text { Absolute value of } \\
\text { export minus } \\
\text { import intensity }\end{array}$ & Intra-industry trade \\
\hline 1973 & 18 & \multicolumn{1}{c}{} & 26 \\
1979 & 22 & 22 & 15 & 33 \\
1988 & 23 & 28 & 16 & 35 \\
1997 & 39 & 42 & 16 & 65 \\
\hline
\end{tabular}

Notes: Import intensity equals imports over imports plus domestic shipments minus exports. Export intensity is exports divided by domestic shipments. Intra-industry trade intensity is export intensity plus import intensity minus the absolute value of export minus import intensity. Shipments are defined as total shipments from manufacturing plants.

Table 10. Correlations between entry, exit, net entry and changes in trade intensity

\begin{tabular}{|c|c|c|c|}
\hline & $\begin{array}{l}\text { Changes in import } \\
\text { intensity }\end{array}$ & $\begin{array}{l}\text { Changes in export } \\
\text { intensity }\end{array}$ & $\begin{array}{l}\text { Changes in intra- } \\
\text { industry trade }\end{array}$ \\
\hline \multicolumn{4}{|c|}{ inturity } \\
\hline $1973-79$ & .04 & .31 & .10 \\
\hline $1979-88$ & .02 & -.13 & -.14 \\
\hline $1988-97$ & .45 & .24 & .31 \\
\hline \multicolumn{4}{|l|}{ Exit } \\
\hline 1973-79 & -.25 & .09 & -.29 \\
\hline $1979-88$ & -.11 & .19 & -.16 \\
\hline $1988-97$ & .48 & .46 & .34 \\
\hline \multicolumn{4}{|l|}{ Net entry } \\
\hline 1973-79 & .31 & .24 & .42 \\
\hline $1979-88$ & -.10 & .13 & .06 \\
\hline $1988-97$ & -.26 & -.37 & -.19 \\
\hline
\end{tabular}

We investigate how entry and exit is related to changing trade patterns in two ways. First, we ask how entry, exit and net entry (the difference between entry and exit) are related in each period to changes in import and export intensity and to changes in the measure of intra-industry trade intensity (Table 10). We expect these correlations to be weak because most of the cross-industry differences should be affected by structural differences. ${ }^{23}$

There is a considerable difference in the relationship between changes in trade and the amount of entry and exit in the two earlier periods. In the 1970s, increases in exports are associated with more entry; increases in imports are associated with less not more exit, and both are associated with higher amounts of net entry. By the 1990s, the relationship between imports and exits has changed. Now increases in imports are significantly associated with more exits; as before, increases in exports are still associated with more entry, but the relationship is more significant. Increases in intra-industry trade lead to both more entry and exit. However, the effect of exit offsets the effect on entry and on balance there is less net entry where imports, exports and intra-industry trade are increasing.

Second, we examine whether the increases in entry between each decade are related to increases in trade intensity between periods (Table 11). Here we ask whether the first difference of the trade change across decades (the increase in export intensity of 1979-88 minus the increase in the export intensity during

23. See Geroski and Schwalbach (1991) for a set of entry studies. 
1973-79) is associated with a change in the rate of entry between two decades (the entry rate in the 1980s minus the entry rate in the 1970s).

\section{Table 11. Correlations between entry, exit, net entry and changes in trade intensity}

\begin{tabular}{lccc}
\hline & $\begin{array}{c}\text { Changes in import } \\
\text { intensity }\end{array}$ & $\begin{array}{c}\text { Changes in export } \\
\text { intensity }\end{array}$ & $\begin{array}{c}\text { Changes in intra- } \\
\text { industry trade }\end{array}$ \\
\hline Entry 1970 s-80s & -0.01 & -0.22 & -0.20 \\
1980s-90s & -0.50 & -0.40 & -0.43 \\
Exit & & & \\
1970s-80s & -0.11 & 0.19 & -0.26 \\
1980s-90s & 0.15 & 0.40 & 0.14 \\
Net entry & & & \\
1970s-80s & 0.09 & -0.39 & 0.04 \\
1980s-90s & -0.43 & -0.59 & -0.37 \\
\hline
\end{tabular}

Between the 1970s and 1980s, increases in export intensity led to lower entry, although the result is not significant. This effect is even larger and very significant between the 1980s and the 1990s. Between the 1970s and 1980s, there are few significant relationships between changes in trade intensity and exit. However, between the 1980s and 1990s, increases in export intensity lead to more exits. The net effect is that changes in intra-industry trade lead to less gross entry and less net entry. Increases in the export intensity associated with trade liberalisation have brought about significantly less entry and slightly more exit. $^{24}$

In summary, increases in trade liberalisation have been accompanied by growth in intra-industry trade. Where this growth was largest, both entry and exit have declined; but the entry rate has fallen more than the exit rate as intra-industry trade has increased.

\subsection{Patterns of entry and exit in innovative industries}

To some observers, high-technology industries appear to be more dynamic than others. In this section, we investigate whether this dynamism extends to the amount of plant turnover and the extent to which entry contributes more here than elsewhere to productivity growth.

To examine these issues, we adopt a taxonomy that aggregates industries into three broad groups that differ in terms of their use of research and development and the intensity of innovation in each - the core, secondary and tertiary "other" sectors. ${ }^{25} \mathrm{We}$ then aggregate the results at the four-digit level to these three broad sectors, using each industry's employment shares, averaged over the beginning and ending years of a period, as weights.

The core sector is more R\&D intensive, creates more innovations than it uses, and distributes some of its innovations downstream to the secondary and tertiary "other" sector in the form of machinery and equipment or new materials. The secondary sector is second in terms of its R\&D intensity and the intensity of innovation. The tertiary "other" sector ingests innovations from the other sectors. ${ }^{26}$

24. We also correlated entry and exit rates with the absolute value of the difference between export and import intensity. There was no significant relationship here for the period between the 1980s and 1990s.

25. This taxonomy comes from Robson et al., 1984.

26. See Baldwin and Hanel (2002) for a detailed analysis of the differences in the innovation regimes of these three sectors. 
The core sector includes ICT-related industries (Machinery and electrical and electronic products) and Chemicals industries. ${ }^{27}$ The secondary sector includes Rubber and plastics, Primary metals, Fabricated metals, Transportation equipment and Non-metallic minerals industries. The rest of the manufacturing industries are classified as the tertiary "other" sector.

As postulated, plant turnover is a more important source of productivity growth in the core sector than in the rest of manufacturing sector in the 1980s and 1990s (Table 12), but the differences are not large. Between 1988 and 1997, plant turnover contributed $21 \%$ of the annual productivity growth in the core sector, compared with $18 \%$ of the annual growth in each of the secondary and other sectors. Plant turnover is also found to be more important for productivity growth in the core sector in the 1979-88 period. However, during the 1973-79 period, plant turnover is more important in the tertiary "other" sector, accounting for more than $30 \%$ of its labour productivity growth.

Table 12. Productivity decomposition by industrial sector

\begin{tabular}{lccrccc}
\hline Industrial sector & LP growth & Within & Between & Net entry & Entry & Exit \\
\hline & & & & & & \\
$1973-79$ & & & & & & \\
Core & 3.00 & 64.19 & 12.42 & 23.39 & 9.51 & 13.87 \\
Secondary & 1.63 & 76.36 & 7.05 & 16.59 & 4.76 & 11.83 \\
Other & 2.15 & 55.92 & 13.37 & 30.71 & 5.14 & 25.57 \\
& & & & & & \\
1979-88 & & & & & & \\
Core & 1.91 & 84.93 & -11.53 & 26.60 & 10.07 & 16.53 \\
Secondary & 1.91 & 90.83 & -2.35 & 11.52 & 3.86 & 7.66 \\
Other & 1.36 & 77.26 & 0.26 & 22.48 & 2.02 & 20.47 \\
& & & & & & \\
1988-97 & & & & & & \\
Core & 5.17 & 76.95 & 2.15 & 20.90 & 0.23 & 20.68 \\
Secondary & 3.05 & 90.98 & -8.77 & 17.79 & 4.65 & 13.14 \\
Other & 1.74 & 89.02 & -6.96 & 17.94 & -4.62 & 22.56 \\
\hline
\end{tabular}

Note: $\quad$ LP growth is annual percentage point growth in labour productivity.

When we further examine the differences between the core, secondary and other sectors with regards to the size of entry and exit, we also find that there are few differences between the core and the other sectors (Table 13). After 1979, plant turnover (as measured by employment shares of entering and exiting plants) was somewhat higher in the core sector $(55 \%)$ than in the rest of manufacturing - although the tertiary "other" sector was a close second at $50 \%$. What really distinguishes the core sector during the 1988-97 period was that the employment share of exiters was highest; the employment share of entrants was similar across the three sectors. Between 1979 and 1988, the employment share of entrants was highest in the core sector, while the share of exiters in the core sector was higher than in the secondary sector but similar to the tertiary "other" sector. In the 1973-79 period, no apparent differences in plant turnover exist between the core, secondary and other sectors.

27. We have excluded Refined petroleum and coal products from the core sector as labour productivity in this industry is subject to large fluctuations due to changes in commodity prices. 
Table 13. Plant turnover by industrial sector

\begin{tabular}{|c|c|c|c|c|}
\hline \multirow[b]{2}{*}{ Industrial sector } & \multicolumn{2}{|c|}{ Entering plants } & \multicolumn{2}{|c|}{ Exiting plants } \\
\hline & $\begin{array}{l}\text { Share of number } \\
\text { of plants }\end{array}$ & Employment share & $\begin{array}{l}\text { Share of } \\
\text { number of } \\
\text { plants }\end{array}$ & $\begin{array}{l}\text { Employment } \\
\text { share }\end{array}$ \\
\hline \multicolumn{5}{|l|}{$1973-79$} \\
\hline $\begin{array}{l}\text { Core } \\
\text { Secondary } \\
\text { Other }\end{array}$ & $\begin{array}{l}39.30 \\
42.10 \\
36.86\end{array}$ & $\begin{array}{l}13.55 \\
11.56 \\
11.98\end{array}$ & $\begin{array}{l}21.70 \\
26.18 \\
31.52\end{array}$ & $\begin{array}{c}11.46 \\
8.60 \\
14.40\end{array}$ \\
\hline \multicolumn{5}{|l|}{ 1979-88 } \\
\hline $\begin{array}{l}\text { Core } \\
\text { Secondary } \\
\text { Other }\end{array}$ & $\begin{array}{l}58.16 \\
56.12 \\
57.95\end{array}$ & $\begin{array}{l}24.35 \\
21.90 \\
22.91\end{array}$ & $\begin{array}{l}42.01 \\
43.77 \\
49.68\end{array}$ & $\begin{array}{l}22.70 \\
15.45 \\
23.46\end{array}$ \\
\hline \multicolumn{5}{|l|}{ 1988-97 } \\
\hline $\begin{array}{l}\text { Core } \\
\text { Secondary } \\
\text { Other }\end{array}$ & $\begin{array}{l}40.16 \\
38.38 \\
38.53\end{array}$ & $\begin{array}{l}20.97 \\
21.81 \\
20.10\end{array}$ & $\begin{array}{l}43.92 \\
40.29 \\
50.12\end{array}$ & $\begin{array}{l}33.58 \\
21.75 \\
29.97\end{array}$ \\
\hline
\end{tabular}

In summary, the evidence supports the notion that in the core innovative sector, plant turnover is more important than elsewhere - both in terms of its size and its contribution to productivity growth. Set against this is the finding that the differences with other sectors are not large.

\section{Conclusion}

In this paper, we examine the effect of plant turnover on labour productivity growth in Canadian manufacturing over the 1973-79, 1979-88 and 1988-97 periods. We find that productivity growth within continuing plants is the predominant source of productivity growth. Plant turnover also makes a contribution as more productive entrants replace exiting plants that are less productive. It contributes $15-25 \%$ of labour productivity growth during the 1973-79, 1979-88 and 1988-97 periods. This contribution is consistently larger than the share of employment in entrants and exits.

Not all entrants are equally important. A disproportionately large fraction of the contribution from plant turnover is due to foreign-controlled firms or multi-plant firms opening up and closing down plants. The plants opened up by foreign-controlled or multi-plant firms are much more productive that other entrants. This finding reinforces other research (Baldwin and Dhaliwal, 2000) that showed foreign plants to have a higher productivity than domestic plants and to be increasing this differential over the last three decades. This paper shows that the difference between foreign and domestic plants is particularly marked for entrants.

Equally important, it reinforces our earlier finding that small domestic plants have not been the engine behind growth (Baldwin, 1998). The proportion of productivity growth that is accounted for by entry has been relatively constant over the last three decades, but the share of this that comes from domestic plants has fallen over this period.

Entering plants undergo both a selection and learning process. Entrants with relatively high productivity and large size are more likely to survive. The surviving members of entering plants experience growth in labour productivity, employment and output. We find that output and employment grow more quickly for surviving entrants than for incumbent plants. However, the productivity growth of the 
surviving entrants is slower than that of incumbents. New plants learn but not as quickly as continuing plants.

Plant turnover is an important source of labour productivity growth in almost all manufacturing industries. However, the cross-industry pattern of the contribution that entrants make has changed over time. Some of this is due to trade liberalisation that has affected the amount of entry and exit at the industry level, but more has come from changes in the relative productivity of new plants - which is probably the result of changes in technology. Finally, in the 1980s and 1990s, plant turnover appears to be a more important source of productivity growth in the ICT-related and Chemicals industries than in the rest of manufacturing. 
Table A1. Decomposition of productivity (value added per worker) in total manufacturing

\begin{tabular}{|c|c|c|c|c|c|c|c|}
\hline & LP growth & Within-plant & Between-plant & Cross-plant & Net entry & Entry & Exit \\
\hline \multicolumn{8}{|l|}{ FHK } \\
\hline $1973-79$ & 2.00 & 78.12 & 23.04 & -22.57 & 21.41 & 5.15 & 16.26 \\
\hline $1979-88$ & 1.13 & 103.18 & 9.14 & -32.78 & 20.45 & -1.48 & 21.94 \\
\hline $1988-97$ & 2.47 & 93.04 & 8.83 & -19.22 & 17.35 & 8.20 & 9.15 \\
\hline \multicolumn{8}{|l|}{ GR } \\
\hline $1973-79$ & 2.00 & 66.78 & 11.02 & -- & 22.20 & -0.56 & 22.76 \\
\hline $1979-88$ & 1.13 & 86.83 & -6.61 & -- & 19.79 & -9.06 & 28.84 \\
\hline $1988-97$ & 2.47 & 83.36 & -4.51 & -- & 21.15 & -0.29 & 21.44 \\
\hline \multicolumn{8}{|c|}{ Baldwin v1 } \\
\hline $1973-79$ & 2.00 & 78.27 & 23.94 & -22.61 & 20.40 & -- & -- \\
\hline $1979-88$ & 1.13 & 103.06 & 7.59 & -32.74 & 22.09 & -- & -- \\
\hline $1988-97$ & 2.47 & 93.10 & 10.25 & -19.24 & 15.89 & -- & -- \\
\hline \multicolumn{8}{|c|}{ Baldwin v1 } \\
\hline $1973-79$ & 2.00 & 66.96 & 12.63 & -- & 20.40 & -- & -- \\
\hline $1979-88$ & 1.13 & 86.69 & -8.78 & -- & 22.09 & -- & -- \\
\hline $1988-97$ & 2.47 & 83.48 & 0.63 & -- & 15.89 & -- & -- \\
\hline
\end{tabular}

Note: Labour productivity is defined as real value added per worker.

Table A2. Decomposition of productivity (value added per worker) in total manufacturing Domestic- vs. foreign-controlled plants: GR approach

\begin{tabular}{lccccc}
\hline Plants & Within-plant & Between-plant & Net entry & Entry & Exit \\
\hline $1973-79$ & & & & & \\
Domestic-controlled & 18.89 & 4.64 & 11.68 & -4.57 & 16.25 \\
Foreign-controlled & 46.53 & 6.12 & 12.14 & 4.86 & 7.28 \\
$1979-88$ & & & & & \\
Domestic-controlled & 27.44 & -0.28 & 5.33 & -16.18 & 21.51 \\
Foreign-controlled & 57.16 & -6.23 & 16.58 & 9.46 & 7.12 \\
$1988-97$ & & & & & \\
Domestic-controlled & 28.04 & -3.32 & 9.57 & -7.77 & 17.34 \\
Foreign-controlled & 54.05 & -1.03 & 12.70 & 8.97 & 3.73 \\
\hline
\end{tabular}


Table A3. Plant turnover and productivity differentials by industry (1973-79)

\begin{tabular}{|c|c|c|c|c|c|c|c|}
\hline \multirow[b]{2}{*}{ Industry } & \multicolumn{2}{|c|}{ Share of the number of plants } & \multicolumn{2}{|c|}{ Employment share } & \multicolumn{3}{|c|}{ Relative LP } \\
\hline & Entrants & Exits & Entrants & Exits & Entrants & Exits & Continuer \\
\hline Food & 26.90 & 32.51 & 8.13 & 13.36 & 1.10 & 0.77 & 1.09 \\
\hline Beverage & 10.14 & 28.41 & 3.50 & 9.37 & 0.76 & 0.48 & 1.00 \\
\hline Tobacco & 26.92 & 24.00 & 2.55 & 14.50 & 1.61 & 0.48 & 1.23 \\
\hline Rubber & 34.75 & 15.38 & 3.48 & 3.60 & 1.02 & 1.10 & 1.16 \\
\hline Plastic & 44.65 & 22.41 & 20.88 & 11.56 & 1.12 & 0.85 & 1.09 \\
\hline Leather and allied & 33.92 & 23.77 & 13.03 & 16.97 & 1.04 & 0.92 & 1.23 \\
\hline Primary textile & 25.70 & 31.76 & 9.99 & 17.09 & 1.11 & 0.70 & 1.29 \\
\hline Textile products & 33.64 & 27.67 & 10.92 & 13.48 & 0.95 & 0.90 & 1.22 \\
\hline Clothing & 34.24 & 32.75 & 17.44 & 20.44 & 1.14 & 0.82 & 1.23 \\
\hline Wood & 44.28 & 36.16 & 16.76 & 18.27 & 1.05 & 0.78 & 1.09 \\
\hline Furniture and fixture & 42.86 & 31.35 & 17.20 & 20.20 & 0.91 & 0.91 & 1.02 \\
\hline $\begin{array}{l}\text { Paper and allied } \\
\text { products }\end{array}$ & 22.01 & 14.92 & 3.90 & 4.11 & 1.04 & 0.65 & 1.05 \\
\hline $\begin{array}{l}\text { Printing, publishing } \\
\text { \& allied }\end{array}$ & 41.38 & 31.56 & 13.70 & 13.45 & 1.05 & 0.81 & 1.16 \\
\hline Primary metal & 24.95 & 17.10 & 5.69 & 1.96 & 1.68 & 0.99 & 1.08 \\
\hline $\begin{array}{l}\text { Fabricated metal } \\
\text { products }\end{array}$ & 43.16 & 25.89 & 17.17 & 12.44 & 1.07 & 0.73 & 1.00 \\
\hline Machinery & 41.57 & 18.51 & 13.64 & 7.03 & 1.11 & 0.87 & 1.11 \\
\hline $\begin{array}{l}\text { Transportation } \\
\text { equipment }\end{array}$ & 44.89 & 33.17 & 10.22 & 9.51 & 0.71 & 0.55 & 1.12 \\
\hline $\begin{array}{l}\text { Electrical and } \\
\text { electronic }\end{array}$ & 45.44 & 24.88 & 16.34 & 15.34 & 1.03 & 0.69 & 1.12 \\
\hline $\begin{array}{l}\text { Non-metallic } \\
\text { mineral }\end{array}$ & 41.03 & 26.94 & 12.50 & 10.79 & 1.02 & 0.87 & 1.11 \\
\hline $\begin{array}{l}\text { Refined petroleum } \\
\text { and coal }\end{array}$ & 24.32 & 20.00 & 10.74 & 6.79 & 0.91 & 0.63 & 1.02 \\
\hline Chemical & 30.39 & 22.24 & 9.32 & 9.22 & 1.39 & 0.65 & 1.16 \\
\hline $\begin{array}{l}\text { Other } \\
\text { manufacturing }\end{array}$ & 45.12 & 30.35 & 17.80 & 13.70 & 0.92 & 0.86 & 1.13 \\
\hline Simple average & 33.14 & 24.86 & 11.08 & 11.44 & 1.03 & 0.74 & 1.07 \\
\hline
\end{tabular}

Note: $\quad$ The relative LP is defined as output per worker relative to that of continuing plants in 1973. The share of exiting plants reflects the share in the base year. The share of entering plants reflects the share in the end year. 
Table A4. Plant turnover and productivity differentials by industry, 1979-88

\begin{tabular}{|c|c|c|c|c|c|c|c|}
\hline \multirow[b]{2}{*}{ Industry } & \multicolumn{2}{|c|}{$\begin{array}{l}\text { Share of the number of } \\
\text { plants }\end{array}$} & \multicolumn{2}{|c|}{ Employment share } & \multicolumn{3}{|c|}{ Relative LP } \\
\hline & Entrants & Exits & Entrants & Exits & Entrants & Exits & Continuer \\
\hline Food & 41.24 & 50.37 & 14.70 & 20.06 & 0.92 & 0.87 & 1.09 \\
\hline Beverage & 23.59 & 37.10 & 4.76 & 16.74 & 0.73 & 0.58 & 1.09 \\
\hline Tobacco & 10.53 & 34.62 & 2.21 & 23.83 & 0.10 & 0.93 & 1.44 \\
\hline Rubber & 51.11 & 30.16 & 11.89 & 9.98 & 1.04 & 1.00 & 0.93 \\
\hline Plastic & 58.89 & 41.49 & 32.04 & 19.30 & 0.96 & 0.75 & 1.11 \\
\hline Leather and allied & 47.80 & 51.78 & 15.26 & 29.69 & 1.15 & 0.89 & 0.97 \\
\hline Primary textile & 40.00 & 40.28 & 12.79 & 26.91 & 1.34 & 0.69 & 1.24 \\
\hline Textile products & 60.98 & 49.67 & 30.93 & 22.65 & 0.82 & 0.77 & 1.09 \\
\hline Clothing & 60.50 & 53.15 & 32.19 & 38.18 & 0.93 & 0.83 & 1.04 \\
\hline Wood & 59.63 & 51.99 & 27.31 & 24.57 & 1.16 & 0.85 & 1.39 \\
\hline Furniture and fixture & 68.70 & 54.44 & 33.69 & 30.91 & 0.82 & 0.82 & 1.03 \\
\hline Paper and allied products & 33.57 & 26.47 & 7.54 & 6.47 & 1.10 & 0.76 & 1.24 \\
\hline Printing, publishing \& allied & 62.09 & 46.41 & 28.93 & 20.42 & 0.91 & 0.79 & 1.06 \\
\hline Primary metal & 37.58 & 32.29 & 11.35 & 5.89 & 1.50 & 0.71 & 1.16 \\
\hline Fabricated metal products & 59.00 & 45.49 & 32.05 & 28.49 & 0.80 & 0.95 & 1.13 \\
\hline Machinery & 62.33 & 43.58 & 32.12 & 31.17 & 0.87 & 0.94 & 1.08 \\
\hline Transportation equipment & 56.88 & 45.22 & 18.02 & 11.18 & 0.84 & 0.53 & 1.33 \\
\hline Electrical and electronic & 61.17 & 45.22 & 23.61 & 21.13 & 1.06 & 0.95 & 1.34 \\
\hline Non-metallic mineral & 48.96 & 43.28 & 23.38 & 18.40 & 0.79 & 0.80 & 1.02 \\
\hline Refined petroleum and coal & 41.79 & 29.73 & 13.72 & 23.56 & 0.45 & 0.86 & 0.95 \\
\hline Chemical & 48.33 & 36.87 & 17.18 & 15.38 & 1.45 & 0.73 & 1.14 \\
\hline Other manufacturing & 66.42 & 53.43 & 35.46 & 33.53 & 0.85 & 0.76 & 1.01 \\
\hline Simple average & 47.87 & 41.00 & 20.05 & 20.80 & 0.90 & 0.77 & 1.08 \\
\hline
\end{tabular}

Note: $\quad$ The relative LP is defined as output per worker relative to that of continuing plants in 1979. The share of exiting plants reflects the share in the base year. The share of entering plants reflects the share in the end year. 
DSTI/DOC(2002)2

Table A5. Plant turnover and productivity differentials by industry, 1988-97

\begin{tabular}{|c|c|c|c|c|c|c|c|}
\hline \multirow[b]{2}{*}{ Industry } & \multicolumn{2}{|c|}{$\begin{array}{c}\text { Share of the number of } \\
\text { plants }\end{array}$} & \multicolumn{2}{|c|}{ Employment share } & \multicolumn{3}{|c|}{ Relative LP } \\
\hline & Entrants & Exits & Entrants & Exits & Entrants & Exits & Continuer \\
\hline Food & 35.50 & 39.51 & 18.40 & 25.69 & 0.89 & 0.89 & 1.14 \\
\hline Beverage & 43.65 & 60.92 & 11.11 & 40.66 & 0.77 & 0.72 & 1.51 \\
\hline Tobacco & 22.22 & 26.32 & 2.57 & 9.79 & 0.14 & 0.94 & 1.27 \\
\hline Rubber & 41.86 & 33.16 & 20.79 & 22.28 & 1.45 & 0.93 & 1.40 \\
\hline Plastic & 37.55 & 36.71 & 25.01 & 21.37 & 0.89 & 0.90 & 1.15 \\
\hline Leather and allied & 35.24 & 62.33 & 18.54 & 50.76 & 0.88 & 0.81 & 1.03 \\
\hline Primary textile & 28.32 & 43.12 & 11.70 & 23.04 & 1.12 & 1.01 & 1.34 \\
\hline Textile products & 40.27 & 53.91 & 20.59 & 38.29 & 0.85 & 0.87 & 1.15 \\
\hline Clothing & 38.83 & 63.76 & 20.51 & 47.05 & 1.28 & 0.92 & 1.17 \\
\hline Wood & 36.40 & 47.38 & 20.95 & 26.27 & 0.88 & 0.72 & 1.10 \\
\hline Furniture and fixture & 41.81 & 59.84 & 25.10 & 45.49 & 1.05 & 0.90 & 1.26 \\
\hline Paper and allied products & 28.57 & 30.50 & 10.62 & 8.60 & 1.26 & 0.72 & 1.24 \\
\hline Printing, publishing \& Allied & 39.74 & 48.49 & 22.87 & 26.82 & 0.81 & 0.87 & 0.88 \\
\hline Primary metal & 26.79 & 33.87 & 6.36 & 7.60 & 1.51 & 0.76 & 1.40 \\
\hline Fabricated metal products & 39.10 & 40.46 & 27.92 & 31.52 & 0.90 & 0.86 & 1.06 \\
\hline Machinery & 39.17 & 42.91 & 22.72 & 33.17 & 1.05 & 0.99 & 1.35 \\
\hline Transportation equipment & 41.24 & 47.62 & 22.35 & 20.28 & 1.09 & 0.64 & 1.38 \\
\hline Electrical and electronic & 42.58 & 46.96 & 19.34 & 36.05 & 1.62 & 0.98 & 2.47 \\
\hline Non-metallic mineral & 36.60 & 37.80 & 21.62 & 26.97 & 0.93 & 0.77 & 1.16 \\
\hline Refined petroleum and coal & 50.00 & 31.58 & 15.54 & 18.59 & 0.41 & 0.74 & 1.49 \\
\hline Chemical & 38.97 & 42.00 & 21.22 & 29.95 & 1.02 & 0.71 & 1.21 \\
\hline Other manufacturing & 42.62 & 50.51 & 31.43 & 36.55 & 0.98 & 0.91 & 1.17 \\
\hline Simple average & 35.96 & 42.59 & 18.14 & 27.25 & 0.95 & 0.81 & 1.23 \\
\hline
\end{tabular}

Note: $\quad$ The relative LP is defined as output per worker relative to that of continuing plants in 1988. The share of exiting plants reflects the share in the base year. The share of entering plants reflects the share in the end year. 
DSTI/DOC(2002)2

Table A6. Productivity decomposition by industry, 1973-79 GR approach

\begin{tabular}{|c|c|c|c|c|c|c|}
\hline & LP growth* & Within-plant & $\begin{array}{l}\text { Between- } \\
\text { plant }\end{array}$ & $\begin{array}{l}\text { Net } \\
\text { entry }\end{array}$ & Entry & Exit \\
\hline Food & 1.96 & 0.79 & 0.33 & 0.84 & 0.19 & 0.65 \\
\hline Beverage & 0.63 & -0.25 & 0.56 & 0.32 & 0.01 & 0.30 \\
\hline Tobacco & 4.93 & 3.22 & 0.42 & 1.29 & -0.05 & 1.34 \\
\hline Rubber & 2.27 & 2.95 & -0.69 & 0.01 & 0.03 & -0.02 \\
\hline Plastic & 1.80 & 0.96 & 0.23 & 0.61 & 0.25 & 0.36 \\
\hline Leather and allied & 3.38 & 2.56 & 0.34 & 0.48 & 0.11 & 0.37 \\
\hline Primary textile & 4.88 & 3.59 & 0.24 & 1.04 & 0.04 & 1.00 \\
\hline Textile products & 3.15 & 2.61 & 0.24 & 0.30 & -0.02 & 0.32 \\
\hline Clothing & 3.83 & 2.24 & 0.48 & 1.10 & 0.51 & 0.59 \\
\hline Wood & 1.99 & 1.13 & 0.01 & 0.86 & 0.13 & 0.73 \\
\hline Furniture and fixture & 0.26 & -0.40 & 0.63 & 0.03 & -0.10 & 0.14 \\
\hline Paper and allied products & 1.03 & 0.71 & 0.04 & 0.29 & 0.06 & 0.22 \\
\hline Printing, publishing \& allied & 2.73 & 2.06 & 0.23 & 0.44 & -0.10 & 0.54 \\
\hline Primary metal & 1.81 & 0.91 & 0.31 & 0.59 & 0.63 & -0.04 \\
\hline Fabricated metal products & 0.84 & 0.00 & 0.17 & 0.67 & 0.36 & 0.31 \\
\hline Machinery & 1.86 & 1.30 & 0.29 & 0.27 & 0.07 & 0.20 \\
\hline Transportation equipment & 1.99 & 1.92 & 0.19 & -0.11 & -0.30 & 0.19 \\
\hline Electrical and electronic & 2.48 & 1.81 & 0.08 & 0.59 & 0.21 & 0.38 \\
\hline Non-metallic mineral & 1.77 & 1.94 & -0.44 & 0.28 & -0.12 & 0.40 \\
\hline Refined petroleum and coal & 0.61 & -11.27 & 11.63 & 0.24 & -0.17 & 0.41 \\
\hline Chemical & 3.38 & 1.90 & 0.59 & 0.89 & 0.41 & 0.49 \\
\hline Other manufacturing & 1.77 & 1.32 & 0.29 & 0.16 & 0.04 & 0.12 \\
\hline Simple average & 2.24 & 1.00 & 0.74 & 0.51 & 0.10 & 0.41 \\
\hline
\end{tabular}

Note: $\quad$ Annual percentage point growth in labour productivity. 
Table A7. Productivity decomposition by industry, 1979-88 GR approach

\begin{tabular}{|c|c|c|c|c|c|c|}
\hline & LP Growth* & $\begin{array}{l}\text { Within- } \\
\text { plant }\end{array}$ & $\begin{array}{l}\text { Between- } \\
\text { plant }\end{array}$ & Net entry & Entry & Exit \\
\hline Food & 1.02 & 0.64 & 0.16 & 0.22 & 0.00 & 0.22 \\
\hline Beverage & 1.64 & 1.33 & -0.09 & 0.40 & -0.10 & 0.50 \\
\hline Tobacco & 4.01 & 3.43 & 0.24 & 0.33 & -0.29 & 0.62 \\
\hline Rubber & -0.69 & -1.01 & 0.16 & 0.16 & 0.17 & -0.01 \\
\hline Plastic & 1.16 & 1.10 & -0.23 & 0.29 & 0.02 & 0.28 \\
\hline Leather and allied & 0.35 & 0.01 & -0.19 & 0.53 & 0.13 & 0.40 \\
\hline Primary textile & 3.46 & 3.38 & -1.21 & 1.28 & 0.37 & 0.91 \\
\hline Textile products & 0.64 & 0.52 & -0.07 & 0.19 & 0.01 & 0.18 \\
\hline Clothing & 0.84 & 0.47 & -0.17 & 0.54 & 0.24 & 0.30 \\
\hline Wood & 3.60 & 2.91 & -0.08 & 0.77 & 0.27 & 0.50 \\
\hline Furniture and fixture & 0.17 & -0.13 & 0.34 & -0.05 & -0.45 & 0.40 \\
\hline Paper and allied products & 2.47 & 2.15 & 0.08 & 0.24 & 0.10 & 0.15 \\
\hline Printing, publishing \& allied & 0.68 & 0.60 & -0.11 & 0.19 & -0.21 & 0.40 \\
\hline Primary metal & 2.21 & 1.48 & 0.17 & 0.56 & 0.45 & 0.12 \\
\hline Fabricated metal products & 0.44 & 0.57 & -0.04 & -0.10 & -0.15 & 0.05 \\
\hline Machinery & 0.34 & 1.07 & -0.32 & -0.40 & -0.65 & 0.25 \\
\hline Transportation equipment & 3.04 & 2.82 & -0.11 & 0.33 & 0.15 & 0.18 \\
\hline Electrical and electronic & 2.83 & 2.86 & -0.49 & 0.45 & 0.11 & 0.34 \\
\hline Non-metallic mineral & 0.07 & 0.07 & 0.00 & 0.00 & -0.04 & 0.04 \\
\hline Refined petroleum and coal & -0.98 & 3.57 & -3.64 & -0.92 & 2.96 & -3.88 \\
\hline Chemical & 2.41 & 1.40 & -0.05 & 1.06 & 0.63 & 0.43 \\
\hline Other manufacturing & 0.39 & 0.16 & -0.01 & 0.23 & -0.01 & 0.24 \\
\hline Simple average & 1.37 & 1.34 & -0.26 & 0.29 & 0.17 & 0.12 \\
\hline
\end{tabular}

Note: Annual percentage point growth in labour productivity. 
Table A8. Productivity decomposition by industry, 1988-97 GR approach

\begin{tabular}{|c|c|c|c|c|c|c|}
\hline & LP growth* & $\begin{array}{l}\text { Within- } \\
\text { plant }\end{array}$ & $\begin{array}{l}\text { Between- } \\
\text { plant }\end{array}$ & Net entry & Entry & Exit \\
\hline Food & 1.27 & 1.30 & -0.16 & 0.13 & -0.12 & 0.25 \\
\hline Beverage & 5.26 & 3.56 & 0.46 & 1.24 & -0.39 & 1.63 \\
\hline Tobacco & 2.47 & 3.27 & -0.74 & -0.05 & -0.24 & 0.19 \\
\hline Rubber & 4.00 & 2.67 & 0.08 & 1.25 & 0.66 & 0.59 \\
\hline Plastic & 1.13 & 1.09 & -0.02 & 0.06 & -0.18 & 0.24 \\
\hline Leather and allied & 1.18 & 0.44 & 0.11 & 0.63 & -0.01 & 0.65 \\
\hline Primary textile & 2.98 & 2.76 & 0.11 & 0.10 & -0.05 & 0.16 \\
\hline Textile products & 1.51 & 0.63 & 0.32 & 0.55 & 0.00 & 0.55 \\
\hline Clothing & 2.42 & 0.88 & 0.38 & 1.15 & 0.41 & 0.74 \\
\hline Wood & 1.44 & 1.41 & -0.31 & 0.33 & -0.18 & 0.52 \\
\hline Furniture and fixture & 2.65 & 1.69 & 0.15 & 0.80 & -0.01 & 0.82 \\
\hline Paper and allied products & 2.70 & 2.57 & -0.16 & 0.28 & 0.16 & 0.12 \\
\hline Printing, publishing \& allied & -1.26 & -0.97 & -0.07 & -0.22 & -0.25 & 0.03 \\
\hline Primary metal & 4.04 & 3.36 & 0.30 & 0.37 & 0.14 & 0.23 \\
\hline Fabricated metal products & 0.69 & 0.76 & -0.32 & 0.25 & -0.05 & 0.30 \\
\hline Machinery & 2.79 & 2.54 & 0.00 & 0.26 & -0.21 & 0.47 \\
\hline Transportation equipment & 3.86 & 3.65 & -0.49 & 0.70 & 0.23 & 0.46 \\
\hline Electrical and electronic & 9.37 & 6.47 & 0.80 & 2.09 & 0.08 & 2.01 \\
\hline Non-metallic mineral & 1.88 & 1.01 & 0.32 & 0.55 & 0.07 & 0.47 \\
\hline Refined petroleum and coal & 3.65 & 3.64 & -0.39 & 0.41 & -0.01 & 0.42 \\
\hline Chemical & 2.74 & 2.59 & -0.46 & 0.62 & 0.06 & 0.56 \\
\hline Other manufacturing & 1.50 & 2.29 & -0.96 & 0.17 & -0.16 & 0.33 \\
\hline Simple average & 2.65 & 2.16 & -0.05 & 0.53 & 0.00 & 0.53 \\
\hline
\end{tabular}

Note: $\quad$ Annual percentage point growth in labour productivity. 


\section{REFERENCES}

Aw, Bee Yan, Xiaomin Chen and Mark J. Roberts (1997), "Firm-level Evidence on Productivity Differentials, Turnover, and Exports in Tawainese Manufacturing", NBER Working Paper, No. 6235 .

Baily, Martin E., Charles Hulten and David Campbell (1992), "Productivity Dynamics in Manufacturing Plants", Brookings Papers on Economic Activity: Microeconomics, pp. 187-249.

Baldwin, John R. (1995), The Dynamics of Industrial Competition, Cambridge University Press, New York.

Baldwin, John R. (1996), "Productivity Growth, Plant Turnover and Restructuring in the Canadian Manufacturing Sector", in D.G. Mayes (ed.), Sources of Productivity Growth, Cambridge University Press.

Baldwin, John R. (1998), "Were Small Firms the Engines of Growth in the 1980s?", Small Business Economics 10, pp. 349-364.

Baldwin, John R., Desmond Beckstead and Andrée Girard (2002), "The Importance of Entry to Canadian Manufacturing with an Appendix on Measurement Issues", STI Working Paper 2002/3, OECD, Paris.

Baldwin, John R., L. Bian, Richard Dupuy and Guy Gellatly (2000), "Failure Rates for New Canadian Firms: New Perspectives for Entry and Exit", Catalogue No. 61-526, Statistics Canada, Ottawa.

Baldwin, John R., Brent Diverty and David Sabourin (1995), Technology Use and Industrial Transformation: Empirical Perspectives, in T. Courchene (ed.), Technology, Information, and Public Policy, John Deutsch Institute for the Study of Economic Policy, Queens University, Kingston, Ontario, pp. 95-130.

Baldwin, John R. and Naginder Dhaliwal (2000), "Labour Productivity Differences between Domestic and Foreign-controlled Establishments in the Canadian Manufacturing Sector", in Productivity Growth in Canada, Catalogue 15-204, Statistics Canada, Ottawa.

Baldwin, John R. and P.K. Gorecki (1991), "Entry, Exit and Productivity Growth", in P.K. Geroski and J. Schwalbach (eds.), Entry and Market Contestability: An International Comparison, Basil Blackwell, Oxford, pp. 244-56.

Baldwin, John R. and Peter Hanel (2002), Innovation and Knowledge Creation in a Small Open Economy, Cambridge University Press, forthcoming.

Baldwin, John R, T. Harchaoui, Judy Hosein and Jean-Pierre Maynard (2001), "Productivity: Concepts and Trends", in Productivity Growth in Canada, Catalogue 15-204, Statistics Canada, Ottawa.

Baldwin, J.R. and M. Rafiquzzaman (1995), "Selection versus Evolutionary Adaptation: Learning and post-Entry Performance”, International Journal of Industrial Organization, 13, pp. 501-522. 


\section{DSTI/DOC(2002)2}

Baldwin, John R. and David Sabourin (2002), "Impact of the Adoption of Advanced Information and Communication Technologies on Firm Performance in the Canadian Manufacturing Sector", STI Working Paper 2002/1, OECD, Paris.

Bartelsman, Eric J. and Phoebus J. Dhrymes (1998), "Productivity Dynamics: U.S. Manufacturing Plants 1972-1986", Journal of Productivity Analysis, 9, pp. 5-34.

Bartelsman, Eric J., and Mark Doms (2000), "Understanding Productivity: Lessons from Longitudinal Microdata", Journal of Economic Literature, 38, pp. 569-594.

Cable, J. and J. Schwalbach (1991), "International Comparisons of Exit and Entry", in P.A. Geroski and J. Schwalbach (eds.), Entry and Market Contestability: An International Comparison, Basil Blackwell, Oxford, pp. 257-281.

Davis, Steven J., John C. Haltiwanger and Scott Schuh (1996), Job Creation and Destruction, The MIT Press, Cambridge, M.A.

Disney, Richard, Jonathan Haskel and Ylva Heden (2000), "Restructuring and Productivity Growth in UK Manufacturing”, CEPR Discussion Paper Series, No. 2463.

Foster, Lucia, John Haltiwanger and C.J. Krizan (1998), "Aggregate Productivity Growth: Lessons from Microeconomic Evidence”, NBER Working Paper, No. 6803.

Geroski, Paul (1991), Market Dynamics and Entry, Basil Blackwell, Oxford.

Geroski, Paul and J. Schwalbach (eds.) (1991), Entry and Market Contestability: An International Comparison, Basil Blackwell, Oxford.

Globerman, Steven (1999), "Implications of Foreign Ownership Restrictions for the Canadian Economy A Sectoral Analysis", Industry Canada Occasional Paper Series No. 7, Ottawa, Canada.

Griliches, Zvi and Haim Regev (1995), "Firm productivity in Israeli industry: 1979-1988”, Journal of Econometrics, 65, pp. 175-203.

Haltiwanger, John (1997), "Measuring and Analyzing Aggregate Fluctuations: The Importance of Building from Micro-economic Evidence", Saint Louis Federal Reserve Bank Economic Review. January/February.

Hazledine, T. (1985), "The Anatomy of Productivity Growth Slowdown and Recovery in Canadian Manufacturing”, International Journal of Industrial Organization 3, pp. 307-26.

Neuman, H. (1978), "Strategic Groups and Structure-Performance Relationship", Review of Economic Statistics, 60, pp. 417-427.

OECD (2001), "Productivity and Firm Dynamics: Evidence from Microdata", OECD Economic Outlook No. 69, OECD, Paris.

Robson M., J. Townsend and K. Pavitt (1988), "Sectoral Patterns of Production and Use of Innovations in the UK: 1945-1983”, Research Policy, 17, pp. 1-14.

Statistics Canada (1979), "Concepts and Definitions of the Census of Manufactures", Statistics Canada Catalogue No. 31-528. 